\title{
Predicted bulk composition of petroleum generated by Lower Cretaceous Wealden black shales, Lower Saxony Basin, Germany
}

\author{
Volker Ziegs • Nicolaj Mahlstedt • Benjamin Bruns • \\ Brian Horsfield
}

Received: 28 March 2014 / Accepted: 18 September 2014 / Published online: 12 October 2014

(C) The Author(s) 2014. This article is published with open access at Springerlink.com

\begin{abstract}
The Berriasian Wealden Shale provides the favourable situation of possessing immature to overmature source rock intervals due to differential subsidence within the Lower Saxony Basin. Hydrocarbon generation kinetics and petroleum physical properties have been investigated on four immature Wealden Shale samples situated in different depth intervals and following the PhaseKinetics approach of di Primio and Horsfield (AAPG Bull 90(7):1031-1058, 2006). Kinetic parameters and phase prediction were applied to a thermally calibrated 1D model of the geodynamic evolution at the location of an overmature well. The immature source rocks of all depth intervals comprise kerogen type I being derived from the lacustrine algae Botryococcus braunii. Bulk kinetics of the lower three depth intervals (sample 2-4) can be described by one single activation energy $E_{\mathrm{a}}$, typical for homogeneous, lacustrine organic matter (OM), whereas sample 1 from the uppermost interval shows a slightly broader $E_{\text {a }}$ distribution which hints to a more heterogeneous, less stable OM, but still of lacustrine origin. Predicted physical
\end{abstract}

Electronic supplementary material The online version of this article (doi:10.1007/s00531-014-1081-y) contains supplementary material, which is available to authorized users.

V. Ziegs $(\bowtie) \cdot N$. Mahlstedt $\cdot$ B. Horsfield

Section 4.3: Organic Geochemistry, Helmholtz Centre,

GFZ German Centre for Geosciences Potsdam,

14473 Telegrafenberg, Potsdam, Germany

e-mail: Volker.Ziegs@gfz-potsdam.de

\section{B. Bruns}

Energy and Mineral Resources Group (EMR), Institute of Geology and Geochemistry of Petroleum and Coal, RWTH

Aachen University, Lochnerstr. 4-20, 52056 Aachen, Germany properties of the generated petroleum fluids are characteristic of variably waxy, black oil possessing GOR's below $100 \mathrm{Sm}^{3} / \mathrm{Sm}^{3}$ and saturations pressures below 150 bar. Petroleum fluids from the more heterogeneous OMcontaining sample 1 can always be described by slightly higher values. Based on the occurrence of paraffinic, free hydrocarbons in the uppermost horizon of the overmature well and gas/condensate in the lower 3 depth intervals, two scenarios have been discussed. From the first and least realistic scenario assuming no expulsion from the source rock, it can be deduced that phase separation in the course of uplift can only have occurred in the uppermost interval containing the slightly less stable OM but not in the lower intervals being composed of a more stable OM. Therefore and taking secondary cracking into account, all depth intervals should contain gas/condensate. The free hydrocarbons in the upper horizon are interpreted as impregnation from migrated hydrocarbons. The second scenario assumes nearly complete expulsion due to fracturing by the so-called generation overpressure (Mann et al. in Petroleum and basin evolution. Springer, Berlin, 1997). The expelled petroleum might migrate into lower pressurised source rock horizons and reach bubble-point pressures leading to the exsolution of gas and "precipitation" of very high molecular weight bitumen unable to migrate. Subsequent burial of the latter in the course of the basin evolution would lead to secondary cracking and remaining pyrobitumen explaining the high amounts of pyrobitumen in the overmature well Ex-B and relatively enhanced TOC contents at such high maturity levels.

Keywords Bulk kinetics · PhaseKinetics ·

Phase behaviour - Type I kerogen - Waxy oil ·

Lacustrine depositional environment .

Unconventionals 


\section{Introduction}

The Lower Saxony Basin (LSB) is the most important oil province of Germany as well as the oldest oil-producing basin in the world, with first production starting as early as 1859. Numerous small- to medium-sized reservoir rocks exist containing between 6.8 and 22.6 trillion $\left(10^{12}\right) \mathrm{m}^{3}$ (240-798 tcf, median: 13 trillion $\mathrm{m}^{3}=459$ tcf) gas-inplace of which $10 \%$ are recoverable reserves (BGR 2012) and 75.5 MMbbls of recoverable crude oil (LBEG 2014; WEG 2013). The hydrocarbon fields are more or less aligned in a NW-SE direction in the LSB, an N-S trending region in the Gifhorn Trough and a NE-SW trend in the West and East Holstein Troughs (including the Mittelplate oil field). Oil is mainly extracted from Middle Jurassic siliciclastic reservoirs, though uppermost Triassic, Cretaceous and Tertiary reservoirs are also present. The crude oils are derived from two sources, namely the Wealden and the Posidonia Shale (e.g. Gifhorn Trough, Schwarzkopf and Leythaeuser 1988) with co-sourced petroleums being commonplace. All oil fields occur in the source rock maturity zone $0.5-0.9 \% R_{0}$ (Kockel et al. 1994). Biodegradation plays a major role in defining oil quality (Blumenstein et al. 2008). The oils generally have a low solution gas-oil ratio; density and viscosity vary (Fabian 1963; Lübben 1969). Petroleum sources are readily distinguished by stable isotopic composition, the isotopically lighter signature being attributed to Posidonia Shale and the heavier to Wealden (Kockel et al. 1994). The contribution of the two sources may also be reflected in the composition of the asphaltenes of migrated bitumens in the Hils Syncline, as seen in the Holzener Asphaltkalk (Horsfield et al. 1991).

The petroleum-generating properties of one of the oil source rocks, the marine Posidonia Shale, have been reported in detail (Rullkötter et al. 1988; Welte et al. 1997 and references therein). For example, the kinetic parameters for petroleum generation from the Posidonia Shale were published by Schaefer et al. (1990) and secondary cracking kinetics by Dieckmann et al. (1998). Source quality, as manifested by chain length distribution, used to define petroleum-type organofacies (Horsfield 1989), was presented by Horsfield and Dueppenbecker (1991); Muscio et al. (1991) showed that these characteristics are carried over from kerogen into genetically related asphaltenes. Petroleum expulsion efficiencies are extremely high, based on mass balance calculations (Rullkötter 1993). It is important to note, within the context of this ICDP Special Issue, that the six shallow research boreholes drilled in the Hils syncline played a key role in enabling fresh (unweathered) sections of the Lias- $\varepsilon$ shales (Posidonia Shale) and part of the overlying Dogger- $\alpha$ mudstones to be cored, and thereafter petroleum generation and migration to be studied as a function of maturity $\left(R_{\mathrm{m}}=0.48-1.45 \% V_{\mathrm{R}}\right)$ for a constant organofacies provided within a natural laboratory.

By comparison, very little coherent information has been published on the petroleum generation characteristics of the Wealden, in part because of its physical and chemical heterogeneity (Pelzer et al. 1992; Elstner and Mutterlose 1996; Mutterlose and Bornemann 2000), most likely related (cf. Berner et al. 2010; Berner 2011) to the combined effects of climatically driven precipitation changes and tectonically driven marine ingressions. The depositional environment of the LSB during the earliest Cretaceous (Berriasian) comprises lacustrine sediments in the basin centre interfingering with fluvial sediments towards the basin margin as well as terrigenous coal-bearing sequences. The basin consists of western, central and eastern parts which underwent differential subsidence and can furthermore be subdivided according to facies distributions and different sedimentation rates (Nebe 1999). The central basin contains up to $700 \mathrm{~m}$ of fluvial-lacustrine mudstones (Elstner and Mutterlose 1996; Mutterlose and Bornemann 2000). Throughout the basin, brackish-lacustrine and marine freshwater conditions alternate, representing short-lived marine ingressions (upper Wealden 2/lower Wealden 3 and upper Wealden 3/ lower Wealden 4, lower Wealden 5), until the depositional environment developed to a full marine one during midValanginian times (Wealden 5 and 6).

The recent release of complete cores from three wells, drilled for shale gas exploration in the LSB, has provided new opportunities for examining the organic geochemical characteristics of the Wealden. Rippen et al. (2013) employed geochemical and petrographical methods to determine the maturity, organofacies and depositional environment of Wealden Shale samples stemming from these wells, and Bruns et al. (2013b) included some of that geochemical data in a 3D basin model of the LSB reconstructing the geodynamic basin evolution. Here, we extend our understanding of the Wealden's source rock properties by predicting the bulk composition of the petroleum it generates as a function of thermal maturity level for each of the major organofacies it displays. The reason for doing so is that the chemical composition of generated petroleum directly controls its physical response (PVT behaviour) to changing pressure and temperature conditions in source and carrier systems during subsidence and uplift, with gas-oil ratio, gas composition and liquid composition having the predominant impact (di Primio et al. 1998; di Primio and Skeie 2004). For instance, an undersaturated petroleum consisting of a single liquid phase containing dissolved gas under sub-surface reservoir conditions will change into a two-phase system during geological uplift or when produced at the surface (England et al. 1987), and the fact remains that a great number of petroleums worldwide have undergone changes in composition due to phase 
behaviour (England and Mackenzie 1989). The PhaseKinetics approach (di Primio and Horsfield 2006) has been utilised to embed PVT predictive properties in a compositional kinetics matrix. To assist in our analysis, bulk kinetic parameters have been integrated into a $1 \mathrm{D}$ model for a mature well (Bruns et al. 2013b and Fig. 1) and the derived phase states compared with the present-day composition of the free hydrocarbons (HC) in a thermally mature well in the LSB (Rippen et al. 2013).

The work here focuses of the main phase of petroleum generation and migration and upon cumulative petroleum charges because interest in conventional petroleum systems in Germany remains relatively high. While the Wealden is one of three potential target horizons for shale gas in Germany (the others are the Posidonia Shale and Lower Carboniferous), its unconventional gas potential at high thermal maturity $\left(R_{\mathrm{m}}>1.2 \%\right)$ is not considered directly here. Our results are nevertheless relatable to shale (tight) oil potential in a general sense.

\section{Materials and methods}

\section{Sample set and bulk characterisation}

The wells Ex-A and Ex-B were drilled in the LSB during 2008 and 2009 in order to sample and test the Wealden for its ability to generate and store hydrocarbons. Both wells were drilled penetrating the central basin facies which consist of thick, homogeneous to laminated mudstone sequences with variable mineral composition and shell fossil content. Samples have been taken from four different depth intervals of the Berriasian Wealden Shale representing dark shales and marlstones. According to Rippen et al. (2013), the samples of the middle depth intervals 2-3 of wells Ex-A and Ex-B represent the lithostratigraphic unit Wealden 3. Correspondingly, samples in stratigraphically higher or lower intervals are of younger or older age, respectively.

A set of 293 samples was geochemically and petrographically described in detail by Rippen et al. (2013), and organic petrography and random vitrinite reflectance $\left(\mathrm{VR}_{\mathrm{r}}\right)$ measurements revealed that organic matter in well Ex-A is thermally immature to early mature with vitrinite reflectances between 0.5 and $0.6 \% \mathrm{VR}_{\mathrm{r}}$. Organic matter in well Ex-B is clearly overmature exhibiting an average vitrinite reflectance of $2.3 \%$. The molecular maturity indices investigated by Rippen et al. (2013) are in good accordance with the vitrinite reflectance measurements.

Here, we have selected four samples (Table 1), chosen for their high TOC contents (full range 0.3-17.5\%), which represent the four depth intervals of well Ex-A and which are characterised by slightly different depositional environments. The organic matter consists mainly of kerogen type I (telalginite and lamalginite) derived from Botryococcus braunii. Variability in Rock-Eval $T_{\max }$ from low to high values $\left(429-452{ }^{\circ} \mathrm{C}\right)$ is related to differences in kerogen structure at a single maturity level.

Open-system pyrolysis [results described in Rippen et al. (2013) and shown in Fig. 2] revealed that kerogen in samples $1-4$ yields a pyrolysate which is dominated by intermediate to long, straight-chained aliphatic hydrocarbons and shows only minor concentrations of aromatic compounds, cycloalkanes as well as sulphur- and oxygenbearing compounds. A paraffinic high-wax oil-generating organofacies can be inferred from the ternary diagram in Fig. 2 (Horsfield 1989). This pyrolysate composition is typically observed for type I organic matter most likely derived from the selective preservation of a highly aliphatic biomacromolecule (algaenan) present in the outer cell walls of lacustrine algae such as B. braunii (Metzger and Largeau 2005; Largeau et al. 1984; Tegelaar et al. 1989). As stated above, algal bodies of $B$. braunii were proven in all studied samples of well Ex-A by petrographical observations (Rippen et al. 2013). Interestingly, the pyrolysate of sample 1 plots on the border to the paraffinic, naphthenic, aromatic low-wax and high-wax oil-generating organofacies fields in Fig. 2, which might be indicative of either input of marineinfluenced algal and hence shorter alkyl-chain-dominated organic material, or a stronger oxidising depositional environment (might explain a higher OI of this sample; compare Table 1 and Sachsenhofer et al. (1995) or higher input (presence) of microbial, bacterial organic matter (Gelpi et al. 1970; Kenig et al. 1990). In any case, sample 1 comprises slightly more heterogeneous organic matter than samples 2-4. It should be also noted that samples of similar depth intervals were shown (Rippen et al. 2013; Fig. 2) to plot in the wax-richer as well as in the wax-poorer part of the paraffinic high-wax field, indicating that the waxpoorer signature is not necessarily evidence for a marine depositional environment.

Organic matter in samples of well Ex-B is late mature to overmature and hence thermally depleted in hydrogen-rich moieties and relatively enriched in aromatic compounds. It exhibits only slightly lower TOC contents than organic matter from well Ex-A and can be classified as type III to IV kerogen, or solid bitumen, according to the S2 versus TOC plot and HI versus $T_{\max }$ diagram (Fig. 6 in Rippen et al. 2013). From the latter plot, it can be deduced that the OM classification of the mature samples of well Ex-B does not reflect the initial kerogen type which is supposed to be of the same quality as in well Ex-A. From open pyrolysis, it can be revealed that the residual OM has a potential for gas and condensate generation left. An interesting feature, revealed by thermovaporisation (compare Rippen et al. 2013), is the presence of paraffinic, waxy oil in the 


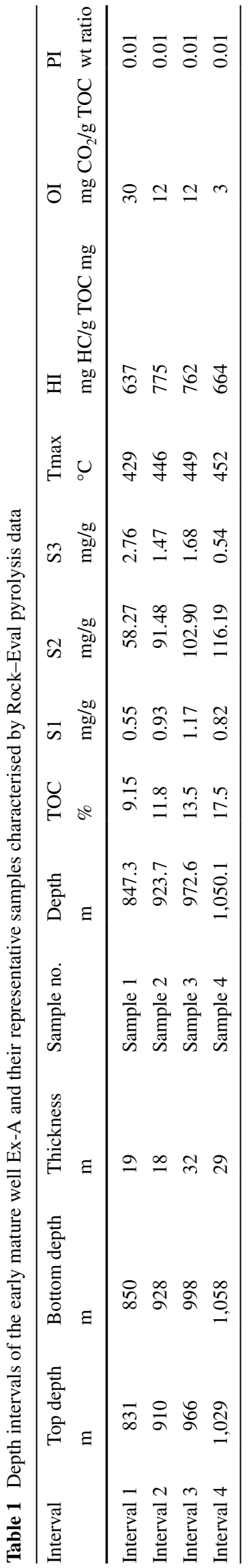

upper depth intervals of well Ex-B, whereas in the lower depth intervals only gas and condensates in relatively low amounts are encountered. This could neither be tracked back to the initial organic matter type, which was shown to be an only slightly different kerogen type I for all depth intervals in well Ex-A, nor to the impact of thermal stress (secondary cracking), as similar free hydrocarbon signatures do as well occur in a less mature well (well Ex-C; VR $\sim 1.6 \%$; compare Rippen et al. (2013)). Alternative explanations might be hydrothermal solution circulating at the base of the successions (Lüders et al. 2012) or, a topic that shall be discussed in the present manuscript, phase separation related to pressure decrease during upwards migration or uplift of a single petroleum phase.

Methods

PhaseKinetics is a compositional kinetic modelling approach based on open- and closed-system (MSSV)pyrolysis gas chromatography to determine petroleumtype organofacies, bulk petroleum generation parameters and bulk compositions at selected transformation ratios and, finally, tuning to configure results in a PVT-amenable format. Here, we perform this workflow on four German Wealden Shale samples and then apply the results in a 1D petroleum system model of a local well (Ex-B) within the LSB. The bulk characterisation of this sample set and hence the petroleum typing has already been published by Rippen et al. (2013) (for description, see previous chapter).

\section{Bulk kinetics using source rock analyzer}

Bulk kinetic modelling is used to determine the kinetic parameters of primary bulk petroleum generation from kerogen using non-isothermal open-system pyrolysis. Whole rock samples were artificially matured at four different heating rates $(0.7,2,5$ and $15 \mathrm{~K} / \mathrm{min})$ using a source rock analyzer (SRA-TPH/IR) from Humble Instruments. 2.2-29.9 mg of sample amount, depending on heating rate and organic matter richness, was weighted into small vessels and heated to temperatures as high as $640{ }^{\circ} \mathrm{C}$. Generated bulk petroleum products are transported to an FID (flame ionisation detector) by a constant helium flow (50 $\mathrm{mL} / \mathrm{min})$. Gained raw data were computed to discrete activation energy $\left(E_{\mathrm{a}}\right)$ distributions consisting of $n=25$ or fewer parallel reactions regularly spaced by $1 \mathrm{kcal} /$ mol (Schaefer et al. 1990; Schenk and Horsfield 1993) and a single variable frequency factor (A in $1 / \mathrm{s}$ ) by using KINETICS2000 and KMOD ${ }^{\circledR}$ (Burnham et al. 1987). The mathematical routine for the first-order kinetic scheme is based on the Arrhenius law (Schenk et al. 1997b; van Heek and Jüntgen 1968) and has been described by Schaefer et al. (1990). 
Micro-scale-sealed vessel pyrolysis (MSSV-Py-GC-FID)

Non-isothermal MSSV closed-system pyrolysis (Horsfield et al. 1989) is a micro-analytical method to artificially mature sedimentary organic matter to different stages of conversion and to qualify and quantify the composition of generated products. It provides the possibility to determine primary and secondary reaction kinetics of specific compound groups and to extrapolate their generation to geological heating rates. This technique consists of two sequential steps: (1) artificial maturation of small aliquots of the original samples in a closed glass tube (micro-scale-sealed vessel) to distinct end temperatures and (2) investigation of the generated products qualitatively and quantitatively on a molecular level by gas chromatography. Small one-sided closed glass capillary tubes of approximately $40 \mu \mathrm{L}$ volume with a bore diameter of $1.0 \mathrm{~mm}$ and a flexure of $120^{\circ}$ were used to carry the weighted sample material. Between 5.0 and $15.5 \mathrm{mg}$ of sample material was filled into the elbow portion of the tube and held by glass wool and quartz sand. The tube was closed by a hydrogen flame. Sample aliquots were artificially matured in a pyrolysis oven consisting of a massive, cylindrical metal block acting as a circular sample holder. A central heating cartridge provided a very homogeneous temperature field throughout the core which is controlled by a thermocouple introduced into one sample holder. For the analytical procedure, a pyrolysis-gas chromatograph from AGILENT Instruments has been used (AGILENT GC 6890A Chromatograph). The MSSV tubes were purged for $5 \mathrm{~min}$ at $300{ }^{\circ} \mathrm{C}$ and then cracked open manually by a purpose-built piston device. Sample products were flushed by a helium flow $(30 \mathrm{~mL} / \mathrm{min})$ to a cryogenic trap which, after removal of the liquid nitrogencontaining Dewar vessel, was ballistically heated to $300{ }^{\circ} \mathrm{C}$ after $10 \mathrm{~min}$. Hydrocarbons fixed in the trap were released via a $50 \mathrm{~m} \times 0.32 \mathrm{~mm}$ capillary column (J\&W Scientific HP-Ultra 1 [Dimethylpolysiloxane phase], $0.52-\mu \mathrm{m}$ film thickness) heated from 30 to $320{ }^{\circ} \mathrm{C}$ at $5{ }^{\circ} \mathrm{C} / \mathrm{min}$. Products were detected using a flame ionisation detector (FID) and displayed as an electric current response in pA. $n$-Butane has been used as an external standard. Prominent hydrocarbons have been identified with the aid of reference chromatograms and manually quantified with "AGILENT ChemStation offline" software by peak area integration.

\section{Compositional kinetic modelling}

After acquiring bulk kinetic parameters of primary petroleum formation from bulk open-system pyrolysis and the composition of first-formed petroleum at transformation ratios of 10, 30, 50, 70 and $90 \%$ from MSSV-pyrolysis, a compositional kinetic model for the prediction of petroleum physical properties $\left(\mathrm{GOR}, \mathrm{B}_{\mathrm{O}}, P_{\text {sat }}\right)$ under subsurface conditions was determined using the PhaseKinetics approach of di Primio and Horsfield (2006). The GOR is the volumetric gas-to-oil ratio of the total gas fraction $\left(\mathrm{C}_{1-5}\right)$ and the total liquid hydrocarbon fraction $\left(\mathrm{C}_{6+}\right)$ at standard surface conditions $\left(\mathrm{Sm}^{3} / \mathrm{Sm}^{3}\right)$. $\mathrm{B}_{\mathrm{O}}$, the formation volume factor, is the ratio of liquid volume in sub-surface to that at surface conditions in $\mathrm{m}^{3} / \mathrm{Sm}^{3} . P_{\text {sat }}$, the saturation pressure, is the pressure when the solution capacity of gas in oil is reached.

PVT modelling is performed using a compositional resolution containing 14 compounds. The seven compounds of the gas range $\left(\mathrm{C}_{1}, \mathrm{C}_{2}, \mathrm{C}_{3}, i-\mathrm{C}_{4}, n-\mathrm{C}_{4}, i-\mathrm{C}_{5}\right.$ and $\left.n-\mathrm{C}_{5}\right)$ are determined by MSSV pyrolysis. As the gas composition is the main controlling factor on phase behaviour and consistently lacks in methane (di Primio and Horsfield 2006), a gas correction was employed based on GOR - gas wetness correlation from natural black oils (di Primio et al. 1998). The liquid range contains a pseudo $\mathrm{C}_{6}$ (corresponding to all compounds eluting after $n-\mathrm{C}_{5}$ until $n-\mathrm{C}_{6}$ ) and a $\mathrm{C}_{7+}$ fraction subdivided into six pseudo-compounds $\left(\mathrm{C}_{7-15}, \mathrm{C}_{16-25}, \mathrm{C}_{26-}\right.$ ${ }_{35}, \mathrm{C}_{36-45}, \mathrm{C}_{46-55}$ and $\left.\mathrm{C}_{56-80}\right)$. The $\mathrm{C}_{7+}$ fraction is characterised by molecular weight and density which is determined by the above-described gas correction and an estimation procedure of di Primio et al. (1998).

\section{$1 D$ petroleum system modelling}

The evolution of the LSB has been unravelled by Petmecky et al. (1999), Bruns et al. (2013b) and selected references therein. Of note to the current article was the rapid subsidence starting at Kimmeridgian (Upper Jurassic) times and reaching its maximum burial depth during Upper Cretaceous times (Petmecky et al. 1999). At the beginning of this tectonic pulse, the LSB became finally differentiated in horst and graben structures indicated by lateral thickness variations (Betz et al. 1987; Petmecky et al. 1999). The following structural inversion of the basin in the Late Cretaceous was most intensive in the former basin centre and led to uplift and erosion of large amounts of Cretaceous and locally older strata of up to 6,700 m (Fig. 1) (Bruns et al. 2013b). The transition from Late Jurassic to Early Cretaceous times was dominated by a regression causing an isolation of sedimentary basins throughout northern Europe (Mutterlose and Bornemann 2000). Smaller Cenozoic inversions during the mid-Paleocene, associated with the Pyrenean tectonic pulse (de Jager 2003), and the Late Eocene again affected the sediments of the LSB (Betz et al. 1987) but insignificantly influenced the general basin history (Fig. 2).

The results of PhaseKinetics and compositional kinetic modelling are linked to the thermal history of a pseudo-well at the drill location of well Ex-B which comprises the highest mature Wealden Shale samples available in this study. 


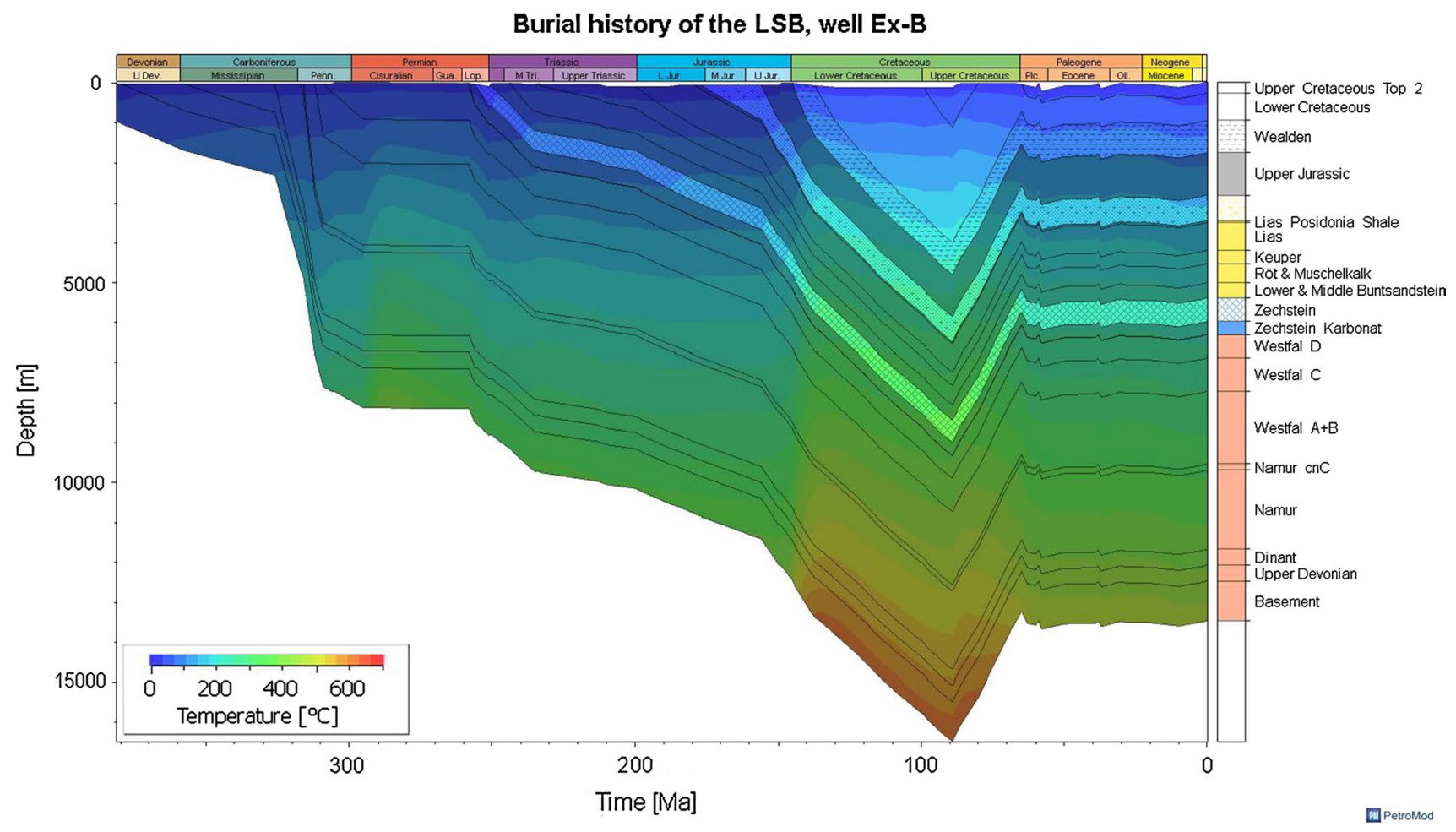

Fig. 1 Basin evolution of the Lower Saxony Basin at the location of well Ex-B, extracted from the 3D basin model provided by the EMR of RWTH Aachen, and displaying the subsurface temperatures throughout geological time

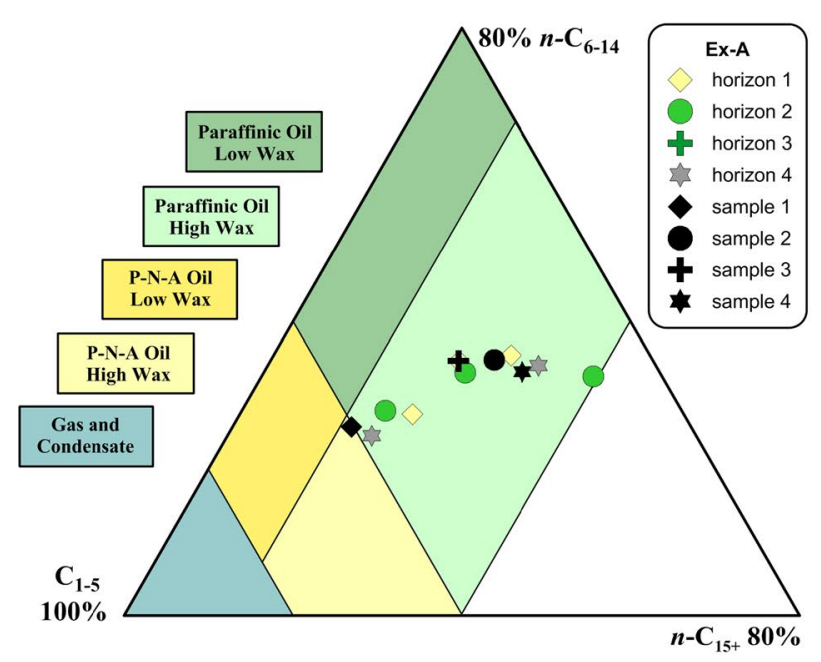

Fig. 2 Open pyrolysis GC-FID: petroleum-type organofacies using the ternary diagram of Horsfield (1989) and GC fingerprints of the corresponding samples of the distinct depth intervals; full circles refer

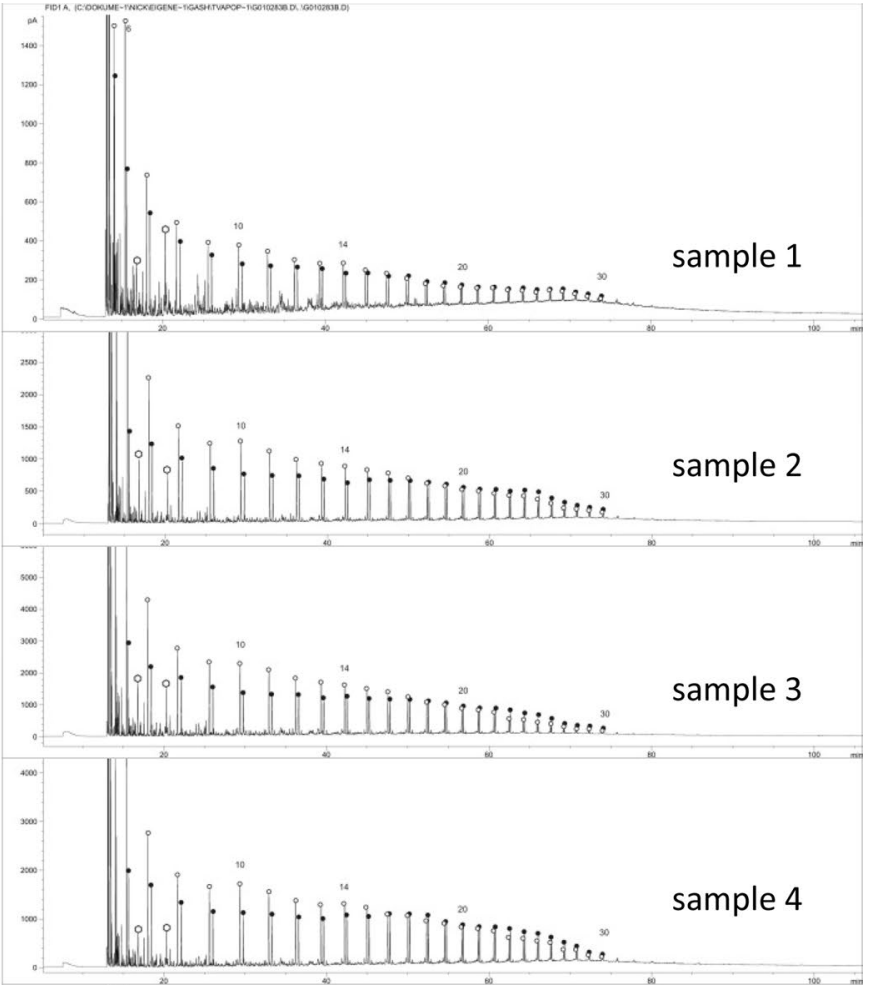

to $n$-alkanes, open circles display alkenes, the small hexagons represent aromates, and numbers refer to the carbon number of $n$-alkanes/ alkenes 

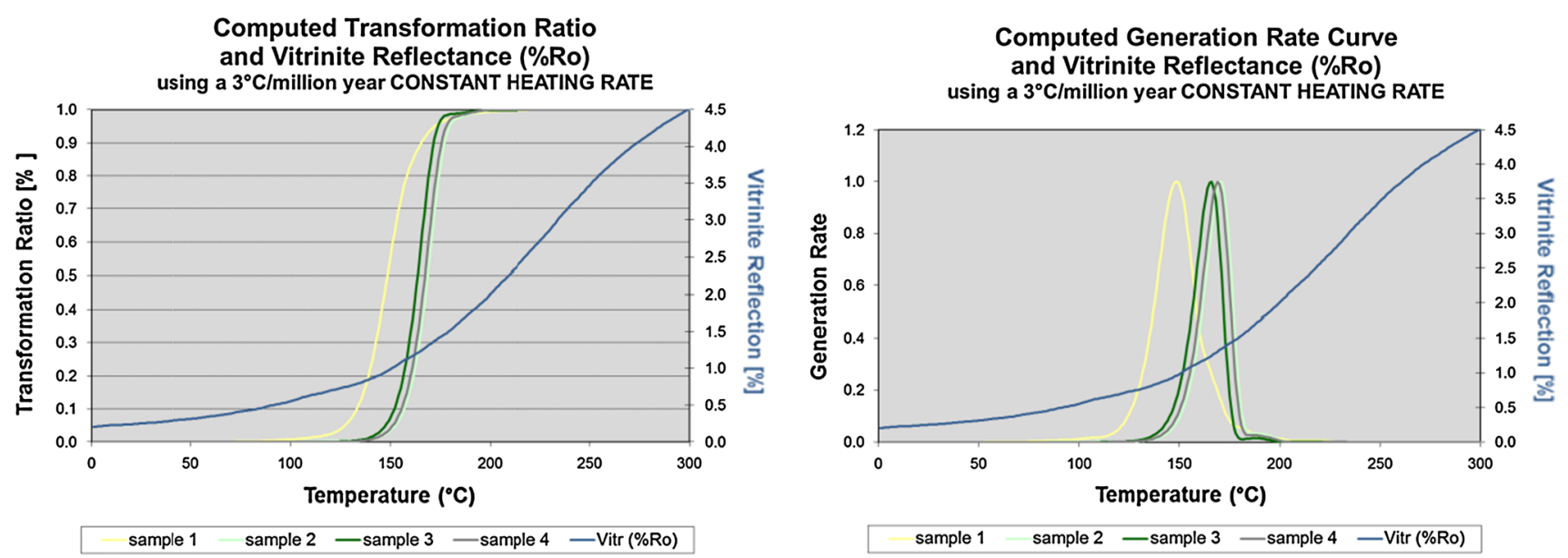

Fig. 3 Computed generation rate curves and transformation ratio curves for a geological heating rate of $3{ }^{\circ} \mathrm{C} / \mathrm{Ma}$ for the investigated Wealden Shale samples

The 1D basin model provided by EMR (RWTH Aachen University) using PetroMod 2012@ was extracted from an already compiled 3D basin model of the LSB containing lithology, source rock characteristics and the kinetic models of the Wealden Shale (Bruns et al. 2013b). As can be revealed from Fig. 1, two major inversion events occurred during the basin evolution of which one had an impact on the burial of the Wealden formation at the location of well Ex-B. The Wealden formation in well Ex-B has been buried up to $4,800 \mathrm{~m}$ during Lower to Upper Cretaceous times and experienced a heating rate of $3.4^{\circ} \mathrm{C} / \mathrm{Ma}$ (Fig. 1). Due to the differential subsidence of the basin (Betz et al. 1987; Brink et al. 1992), this heating rate is only valid at this specific area. In a last step and for kinetic considerations, bulk kinetic parameters of samples 1 and 4 have been assigned to the Wealden shale formation. These samples were selected because they are representative for the deposition of the Wealden Shale which was mainly of lacustrine origin intercalated with short-termed marine transgressions (Elstner and Mutterlose 1996). For more detailed descriptions of the basin model and its boundary conditions, refer to Bruns et al. (2013b).

\section{Results}

Lability of organic matter (bulk kinetic parameters)

The calculated activation energy distributions $\left(E_{a}\right)$ and single pre-exponential factors (A) for the four Wealden Shale samples are given in Table S2 (Supplementary) and shown in Fig. 3. The data hint to the origin of the organic matter within distinct organofacies as the width of the $E_{\mathrm{a}}$ distribution is more or less directly related to kerogen heterogeneity and hence depositional environment (e.g. Tissot et al.
1987). Thus, sample 1 shows a marine signature, at least in the classical sense (Tegelaar and Noble 1994; Pepper and Dodd 1995), by displaying a relatively broad $E_{\mathrm{a}}$ distribution with values ranging between 44 and $64 \mathrm{kcal} / \mathrm{mol}$ and a main energy at $55 \mathrm{kcal} / \mathrm{mol}$ accounting for $45 \%$ of the total kerogen to petroleum conversion reaction, whereas Wealden Shale samples 2-4 from the lower depth intervals display an $E_{\mathrm{a}}$ distribution which is dominated by one single $E_{\mathrm{a}}$, between 58 and $60 \mathrm{kcal} / \mathrm{mol}$, accounting for at least $96 \%$ of the total kerogen to petroleum conversion reaction. Domination of a single activation energy is commonly thought to be characteristic for lacustrine type I source rocks (Pepper and Corvi 1995) and reflects a homogeneous mainly polymethylene kerogen structure which is most likely inherited by selectively preserved aliphatic algaenan, the resistant biopolymer from within the outer cell walls of microalgae, such as B. braunii (de Leeuw and Largeau 1993; Tegelaar and Noble 1994), and comprises only a limited range of chemically stable bonds. The frequency factor of the more heterogeneous sample $1\left(3.84 \mathrm{E}+14 \mathrm{~s}^{-1}\right)$ is also lower than those of samples $2-4(1.12 \mathrm{E}+15$ to $5.30 \mathrm{E}+15 \mathrm{~s}^{-1}$ ) indicating a lower thermal stability.

With respect to the broader $E_{\mathrm{a}}$ distribution of sample 1 , it should be noted that heterogeneous (broad $E_{\mathrm{a}}$ distributions) as well as homogeneous (single $E_{a}$ ) type I kerogens are found in lacustrine settings, as reported, for example, in the Laney Shale and Luman Tongue of the Green River Shale (Horsfield et al. 1994) or in the ES4 member of the Shahejie Formation in the Western Depression of the Liaohe Basin, NE China (Fuhrmann et al. 2004). It is clear that kinetic parameters vary appreciably, even within lacustrine settings, and therefore, evaluations should be conducted on a case-by-case basis. It is therefore also clear that based solely on the $E_{\mathrm{a}}$ distribution sample 1 cannot be assigned a marine depositional origin. 
Extrapolation of the petroleum-forming reaction to geological heating rates might yield better clues concerning the depositional origin of the samples. Assuming a hypothetical geological heating rate of $3{ }^{\circ} \mathrm{C} / \mathrm{Ma}$, transformation ratio rate curves (Fig. 3) indicate that samples 2-4 exhibit higher onset $\left(10 \%\right.$ TR) temperatures $\left(152-157{ }^{\circ} \mathrm{C}\right)$ and peak petroleum generation temperatures $\left(T_{\max }=165-170.5^{\circ} \mathrm{C}\right)$ than sample 1 from the uppermost depth interval (see Table S2). Nevertheless, onset and peak petroleum generation temperatures for sample $1,133.2^{\circ} \mathrm{C}$ and $148.4{ }^{\circ} \mathrm{C}$, respectively, hint as well to a rather high thermal stability. On the one hand, its geological $T_{\max }$ value resembles those of the stable, S-poor, type II marine shales sample set of Tegelaar and Noble (1994) and Braun et al. (1991) in which $T_{\max }$ values range between 142 and $150{ }^{\circ} \mathrm{C}$. On the other hand, the extrapolation is also comparable to geological predictions for thermally less stable lacustrine samples (e.g. from wells AP24: Anvil Points 24 gal/ton and GOVT: Government 33-4 from the Uinta Basin) published in Braun et al. (1991), which exhibit calculated $\mathrm{T}_{\max }$ values between 147 and $149{ }^{\circ} \mathrm{C}$, as well as for lacustrine type I samples from the ES4 member of the Shahejie Formation in the Western Depression of the Liaohe Basin, NE China, published in Fuhrmann et al. (2004), which exhibit calculated $T_{\max }$ values between 148 and $159^{\circ} \mathrm{C}$.

Predictions to geological heating rates for Wealden Shale samples 2-4 result in thermal stabilities which are slightly higher than predictions for most of the lacustrine kerogens poor in sulphur and aromatic compounds compiled by Tegelaar and Noble (1994) and Braun et al. (1991). Green River Shale samples (e.g. from wells Brotherson 1-23B4 and Government 33-4) from Uinta Basin (Braun et al. 1991) and Pematang samples [Indonesian Brown Shale, (Tegelaar and Noble 1994)] exhibit maximum generation potentials $\left(T_{\max }\right)$ ranging between 147 and $165{ }^{\circ} \mathrm{C}$. Horsfield et al. (1994) reported geological $T_{\max }$ values of $150-170{ }^{\circ} \mathrm{C}$ for the Laney Shale member and $T_{\max }$ values of $170-175{ }^{\circ} \mathrm{C}$ for the Luman Tounge member of the Green River Formation (Washakie Basin). In the case of an Australian Torbanite composed of the remains of $B$. braunii, an even higher maximum petroleum generation rate temperature of $180{ }^{\circ} \mathrm{C}$ was reached (Tegelaar and Noble 1994). In a related context, Behar et al. (1995) have shown that different B. braunii races possess different thermal stabilities, for example, the structure of race $\mathrm{L}$ contains $\mathrm{C}_{40}$ isoprenoid chains with a lycopenetype skeleton which are less stable than the long polymethylenic chains of the race B cell walls consist. Botryococcus braunii algae within Wealden Shale samples 2-4 might therefore be derived from algal remains belonging to a rather stable race.
Compositional kinetic model and calculated fluid physical properties

Compositional kinetic models were generated for four samples of which each represents a depth interval of the immature well Ex-A. The compositional evolution and physical properties of the fluids generated at increasing degrees of transformation were determined using MSSV pyrolysis and are shown in Table S3 and Fig. 4. The observations made based on the activation energy distributions and carbon chain length distributions from pyrolysis are generally supported by the results shown. A paraffinic high-wax petroleum type was predicted for all samples; thus, the fluids generated fall within the black oil class, as defined by petroleum engineers (McCain 1990). Even at $90 \%$ TR they do not reach saturation pressures of 200 bars (approximate start of volatile oil) and exhibit, over the entire primary kerogen conversion range, more or less uniform and very low saturation pressures around $80-115$ bar in the case of the wax-richer samples 2-4 and between 113 and 150 bar in the case of sample 1 . The same is true for GOR values that range around $50 \mathrm{Sm}^{3} / \mathrm{Sm}^{3}$ in the case of the wax-richer samples 2-4 and between 75 and $103 \mathrm{Sm}^{3} / \mathrm{Sm}^{3}$ in the case of sample 1. The evolution of the physical properties, that is, more or less uniform GOR's and saturation pressures, of fluids generated from all samples can therefore be described as typically lacustrine, whereas the physical properties of fluids generated from the rather heterogeneous, less stable sample 1 are simply slightly increased.

Natural hydrocarbon fluids generated from the same source rock as a function of increasing maturity display a linear correlation of $P_{\text {sat }}$ and GOR and of $P_{\text {sat }}$ and $\mathrm{B}_{\mathrm{O}}$ (di Primio et al. 1998). This has also been proven to be valid for source rock maturation series investigated by MSSV pyrolysis (di Primio and Horsfield 2006). The petroleum fluids from all here investigated samples show a slight increase in $P_{\text {sat }}$ and $\mathrm{B}_{\mathrm{O}}$ with increasing TR and in a cross plot of these two properties plot in the area of naturally occurring petroleum fluids (Fig. 4). It can be seen in the $P_{\text {sat }}$ versus $\mathrm{B}_{\mathrm{O}}$ plot (Fig. 4) that the generated fluids range only within a very limited area which is a typical behaviour for homogeneously structured kerogens of lacustrine origin (see discussion in Horsfield (1989)). Nevertheless, overall slightly lower $\mathrm{B}_{\mathrm{O}} / \mathrm{GOR} / P_{\text {sat }}$ fluids were generated from samples $2-4$ containing homogeneous and more stable kerogen (Fig. 4).

It should be noted that for all samples GORs slightly increase when reaching a transformation ratio of $90 \%$. This indicates higher gas generation most likely related to the onset of secondary cracking of primarily formed petroleum compounds. 

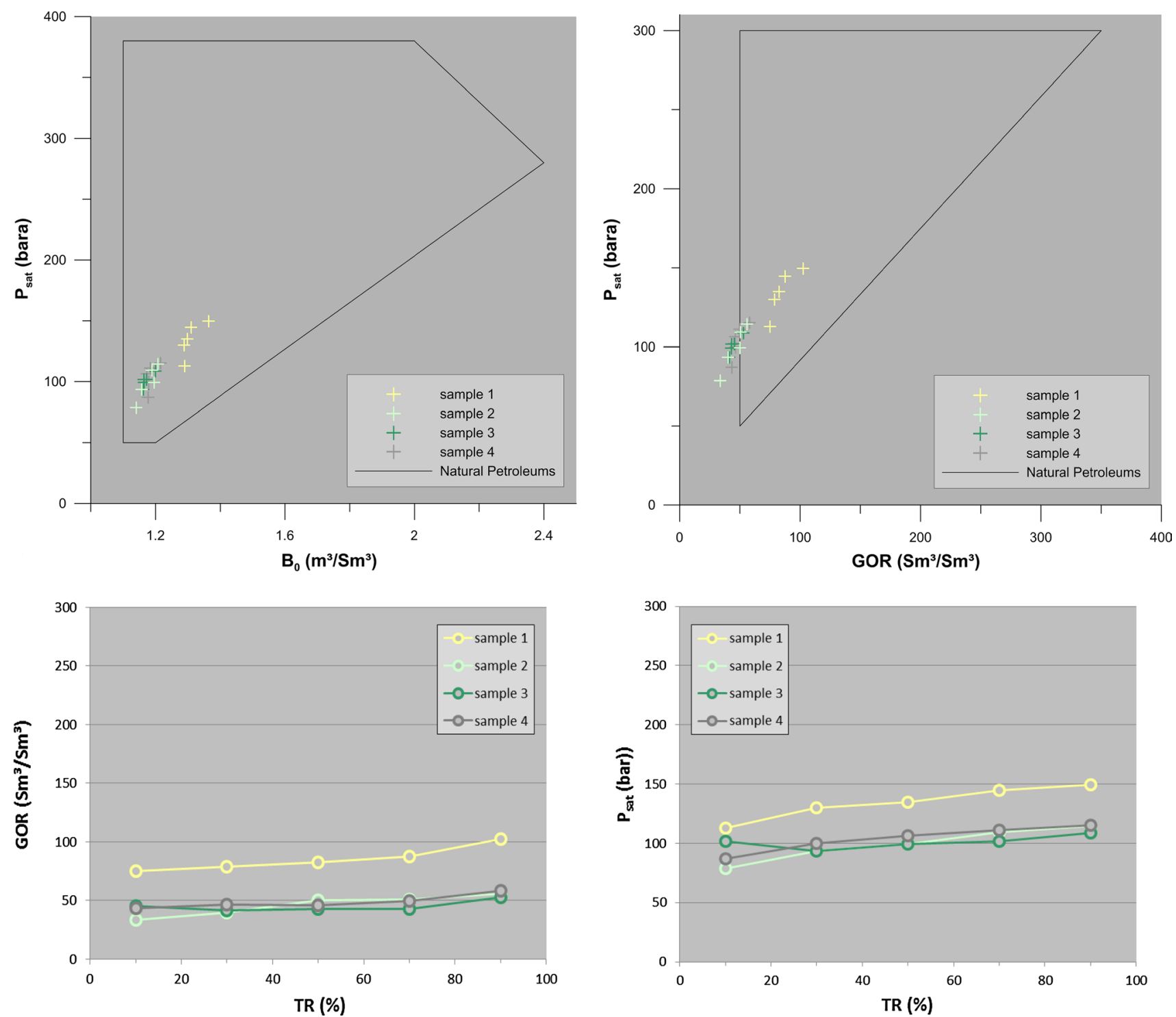

Fig. 4 Physical properties of representative early mature Wealden Shale samples originating from different depositional environments plotted in a $P_{\text {sat }}$ versus $\mathrm{B}_{\mathrm{O}}$ diagram (upper left), $P_{\text {sat }}$ versus GOR

(upper right) and GOR as well as $P_{\text {sat }}$ versus TR representing maturity (lowermost diagrams)

\section{Discussion}

\section{Phase envelopes}

The predicted phase envelopes of cumulative fluids generated from Wealden Shale rock samples at five transformation ratios were calculated using PVTsim $\odot$ and are displayed in Fig. 5. The shape of the phase envelopes strongly depends on the composition of the fluids and thus on maturity or precursor origin; the quantity of light hydrocarbons dissolved in the liquid phase (GOR) has the largest influence. As can be deduced from Fig. 6, the Wealden Shale samples possess a high oil generation potential of around $90 \%$ throughout maturation and hence a low gas

generation potential (8-12\%) of which methane accounts for one-third. Thus, "loaf-shaped" phase envelopes, which are characteristic for black oils, can be observed for all investigated samples, but nevertheless the phase envelopes of the homogeneous samples 2-4 are "flatter" than those of the more heterogeneous sample 1 . This can be explained by a slightly higher gas generation potential of the latter sample in comparison with samples $2-4$. The cricondentherm and critical point are influenced by molecular weight and density of the $\mathrm{C}_{7+}$ fraction. High molecular weights and densities result in a high cricondentherm, a low GOR and a low $P_{\text {sat }}$, a feature qualitatively observable for all investigated samples. Homogeneous samples 2-4 show almost identical pT-characteristics with similar cricondenbar 
sample 1

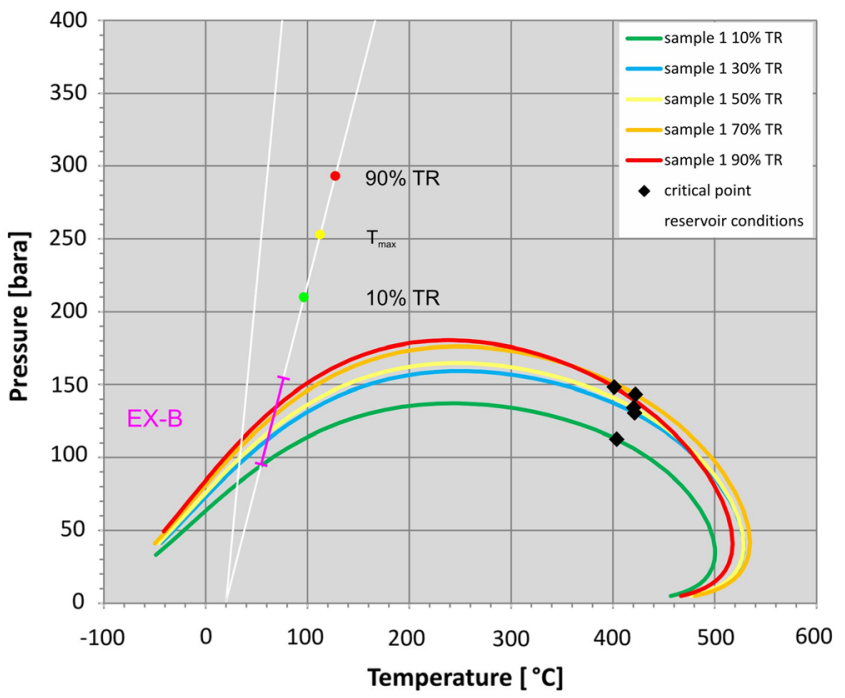

sample 3

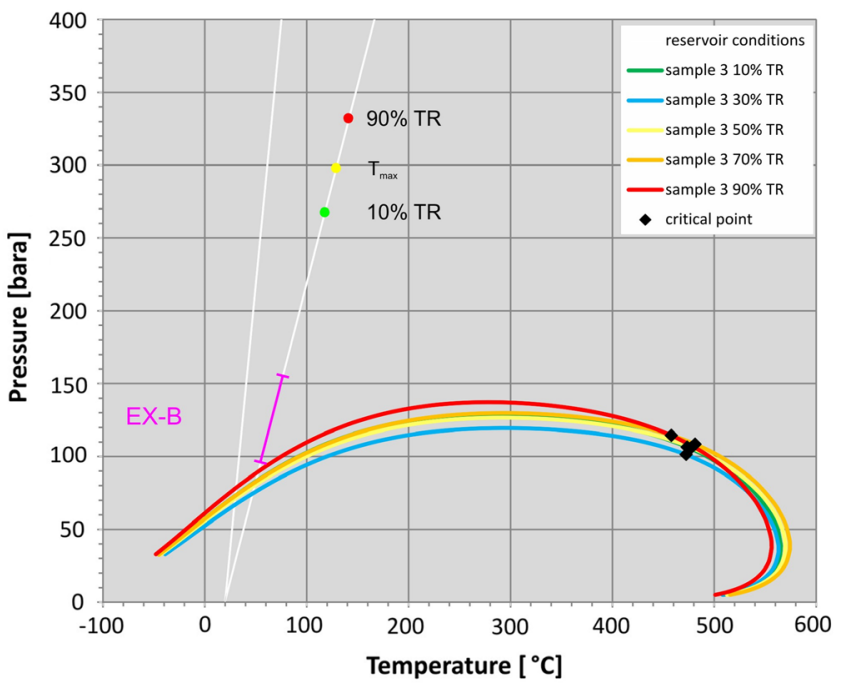

Fig. 5 Phase envelopes of the petroleum generated primarily at different transformation ratios of samples 1-4. Additionally, calculated present-day pT-conditions (hydrostatic) within the overmature well

(138-141 bar) and cricondentherm values $\left(564-574{ }^{\circ} \mathrm{C}\right)$ as well as more or less similar critical points ranging between 466 and $481{ }^{\circ} \mathrm{C}$, respectively, 109 and 116 bar at a transformation ratio of $70 \%$. The fluid composition at $70 \%$ TR can be viewed as being characteristic of cumulatively generated primary petroleum, whereas at $90 \%$ TR cracking of $\mathrm{C}_{6+}$ compounds might have already led to the formation of secondary gas. The more heterogeneous sample 1 exhibits phase envelopes with bubble-point curves extending to higher cricondenbars (176 bar at $70 \%$ TR) and dew point curves extending to lower cricondentherms $\left(535{ }^{\circ} \mathrm{C}\right.$ at $70 \% \mathrm{TR}$ ). This is consistent with the sample's slightly higher gas-generative potential induced by differences in sample 2

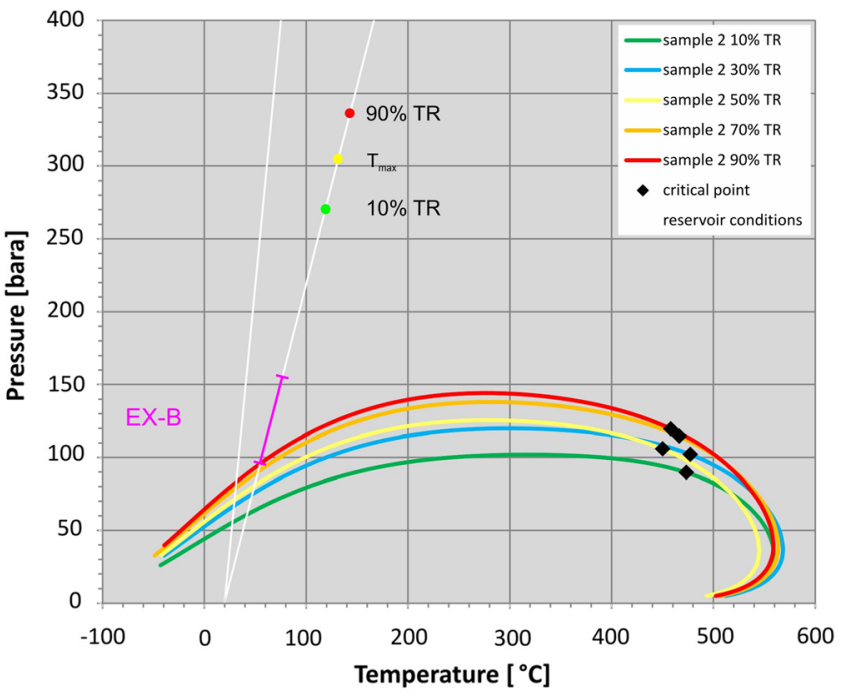

sample 4

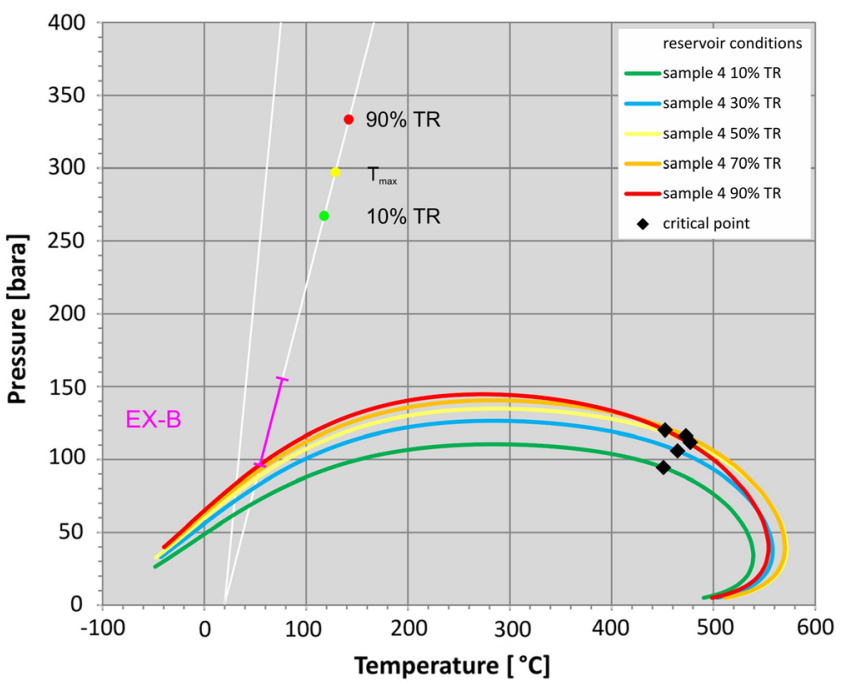

Ex-B are indicated as well as pT-conditions of the primary generation window as revealed from bulk kinetics (Fig. 3 and Table S2)

the organic matter structure of petroleum precursors (di Primio et al. 1998).

In general and with increasing maturity (10-90\% TR), a systematic decrease in cricondentherm and increase in cricondenbar can be expected for type II and type III kerogens, as well as a shift of the critical point towards higher pressures and lower temperatures (di Primio et al. 1998). Interestingly, for all investigated samples, critical points move towards higher pressures but not progressively to lower temperatures with increasing maturity. Both cricondentherm and cricondenbar partly increase with maturity. Some samples show at least a "crossover area" in which critical points move first to higher temperatures before 

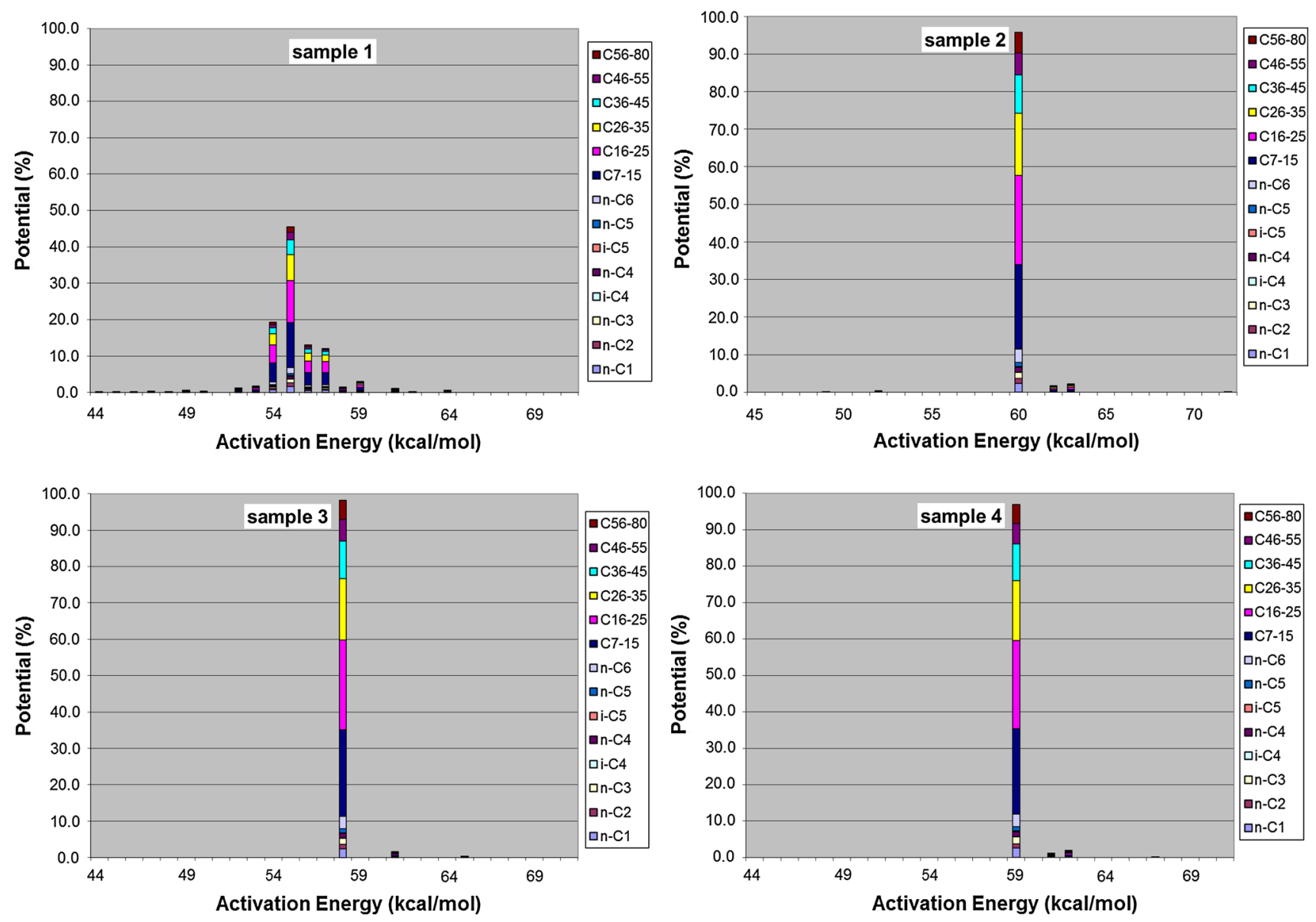

Fig. 6 Activation energy distributions of four immature Wealden Shale samples with integrated compositional information

decreasing to lower ones while they steadily increase in pressure. Maturation of a type I kerogen proceeds within a very limited temperature interval in which the OM (here mainly remains of $B$. braunii) is converted into petroleum at a very fast rate, that is, within a temperature interval of $20{ }^{\circ} \mathrm{C}$ for samples $2-4$ and within a temperature interval of $32{ }^{\circ} \mathrm{C}$ for sample 1 (Table S2, Fig. 3). Thus, the gas composition as well as the GOR does not change significantly throughout maturation as it does for more heterogeneous kerogen types II and III (Kuhn et al. 2010). Consequently, the evolution of the shape of phase envelopes for sample 1 is entirely consistent with its purported lacustrine origin.

Phase behaviour prediction

Phase behaviour of generated petroleum fluids for four early mature Wealden Shale samples from four depth intervals of well Ex-A (Table 1) was calculated for temperatures corresponding to transformation ratios of $10,30,50,70$ and $90 \%$ (see Table S3). Secondary cracking of generated products at high temperatures was only considered theoretically in the scope of this work as the fate of migrating primary fluids was of prime importance. To predict the phase state of generated products within the sedimentary column, PhaseKinetic results are compared to the provided 1D basin model for well Ex-B which includes an average standard linear geopressure gradient of $100 \mathrm{bar} / \mathrm{km}$ and, in the case of the LSB, an average linear geothermal gradient of up to $34.4{ }^{\circ} \mathrm{C} / \mathrm{km}$ (as extracted from the provided model of Bruns et al. 2013a, b). As the lithostratigraphic column of the Berriasian Wealden formation is dominated by organic matter deposition in a lacustrine freshwater environment with intercalations of only short-lived marine transgressions (Elstner and Mutterlose 1996; Mutterlose and Bornemann 2000), we applied kinetic parameters of samples comprising lacustrine type I organic matter of either heterogeneous character, represented by sample 1 (Fig. 7a), or homogeneous character, represented by sample 4 (Fig. 7b).

Even though increased amounts of vitrinite and inertinite were found in samples of well Ex-B, locally indicating input of terrestrial higher land-plant-derived organic matter (Rippen et al. 2013) or sedimentological differences in the facies of the organic-rich interval, the major part 


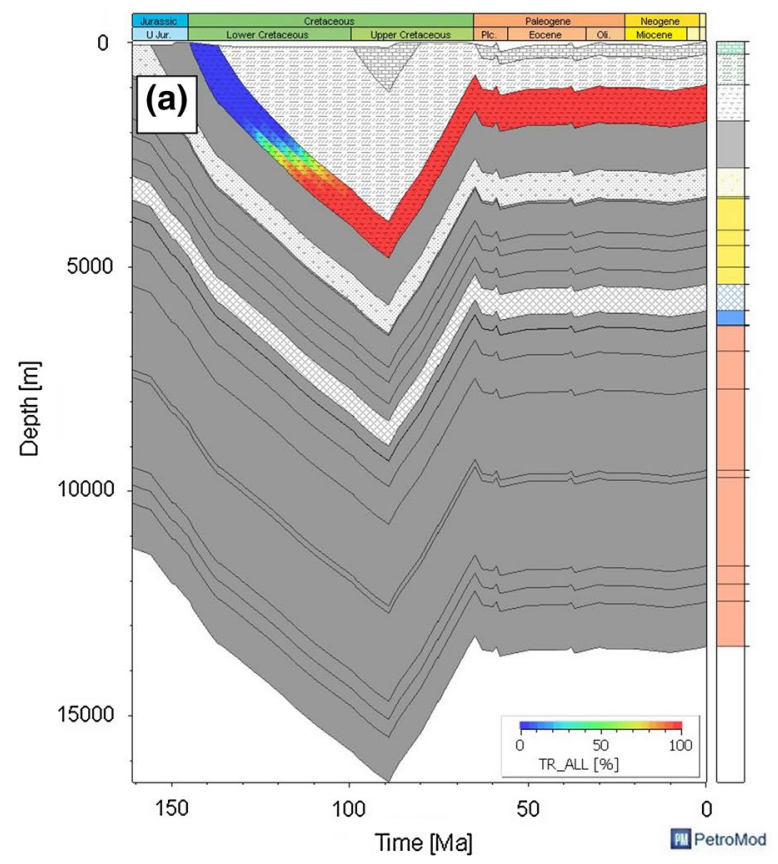

Fig. 7 Transformation ratios of the primary petroleum generation obtained from the bulk kinetic descriptions (Fig. 3) of sample 1 (a) and sample 4 (b) applied to the burial history of the LSB at well loca-

of the petroleum-generating organic matter fraction can be assumed to have also consisted of the remains of the lacustrine, algal material found in well Ex-A. In addition, high amounts of pyrobitumen found in samples of well Ex-B rather represent migrated than in situ petroleum residues and therefore impregnated adjacent rather than initial source intervals of the Wealden succession (discussed in the following; "second scenario"). Thus, kinetics of petroleum generation and evolution of physical properties of the generated fluids from representative intervals of well Ex-B most likely were largely similar to those predicted for samples from well Ex-A and can be used in the 1D basin model.

The Wealden Shale was deposited during the earliest Cretaceous (Berriasian) from 145 to 137 Mya and instantly underwent a rapid burial to $4,800 \mathrm{~m}$ within $56 \mathrm{Ma}$ (until 89 Mya) in the area of well Ex-B (Figs. 1, 7). During subsidence to the maximum burial depth, the deposited organic matter passed through the oil and gas generation window. The onset of primary hydrocarbon generation from shales comprising stable, homogeneous type I organic matter as found in sample 4 occurred later, ca. 115 Mya at a depth of $\approx 2,670 \mathrm{~m}$, whereas the generation from less stable, heterogeneous type I organic matter as found in sample 1 occurred earlier, ca. 122 Mya at $\approx 2,100 \mathrm{~m}$ depth. This corresponds to subsurface (hydrostatic) pressures of $\approx 267$ and $\approx 210$ bar, respectively. With ongoing burial maximum petroleum generation rates $\left(T_{\max }\right)$ were reached at $110 \mathrm{Mya}$

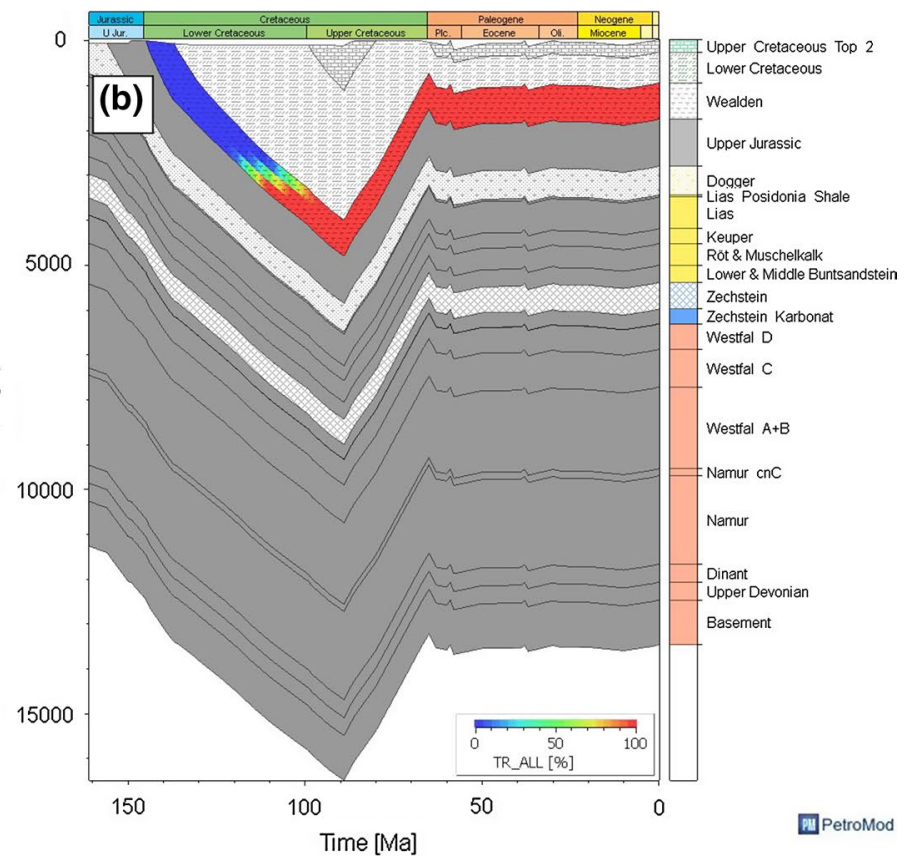

tion Ex-B (Fig. 1). The geological temperatures and vitrinite reflectances of the distinct stages of petroleum formation are denoted in Table 3 (supplementary)

for sample 4 and at 117 Mya for sample 1, whereas the offset of primary petroleum generation $(\mathrm{TR}=90 \%)$ was reached at 105 Mya $(3,313 \mathrm{~m})$ for sample 4 and at 111 Mya $(2,950 \mathrm{~m})$ for sample 1 . Thus and in accordance with the bulk kinetic predictions (Table S2), the petroleum generation from stable, homogeneous lacustrine organic matter starts at greater depth (570 m deeper) and higher temperatures than petroleum generation from less stable, heterogeneous lacustrine organic matter. The generation window for the former one (sample 4) extends over a smaller depth interval $(650 \mathrm{~m})$ and time span $(9.5 \mathrm{Ma})$ in comparison with the latter one (sample 1), where the generation window extends over $11 \mathrm{Ma}$ and a depth interval of $850 \mathrm{~m}$. According to the phase envelopes (Fig. 5), all hydrocarbons generated between 10 and $90 \%$ TR, independently of organic matter origin or heterogeneity, occur in a single-phase state as undersaturated liquid petroleum at depth of generation because hydrostatic subsurface pressures of 268-332 bar for sample 4 and 210-293 bar for sample 1 are higher than geologically realistic bubble-point pressures which range from 70 to 95 bar for sample 4 and from 90 to 135 bar for sample 1. The given bubble-point pressure can be deduced from the intersection of the hydrostatic pressure gradient with the phase envelopes in Fig. 5.

As can be revealed from the burial history of the LSB (Fig. 1), the organic and inorganic matter of the Wealden Shale experienced a relatively simple structural evolution of burial to maximum depth and subsequent geological 
uplift to more or less present-day depth. In the following, we discuss the fate of generated petroleum fluids, that is, their phase behaviour within the sediment column, in the light of two "end-member" scenarios. In the first one, termed "unconventional setting", zero expulsion of generated hydrocarbon products is assumed, whereas in the second, more realistic one, expulsion of the major part of generated hydrocarbons is assumed.

During geological uplift in the Upper Cretaceous (Figs. 1, 7), subsurface pressure and temperature decreased. For retained hydrocarbons in an "unconventional setting", phase separation might have occurred during the uplift phase once the bubble-point pressures and temperatures of the generated hydrocarbon fluids from samples 1 and 4 were reached. As described previously, phase envelopes of sample 1 exhibit elevated bubble-point pressures (see Table S3 for a hypothetical reservoir temperature of $100{ }^{\circ} \mathrm{C}$ ) in comparison with those of the homogeneous sample 4. Petroleum fluids generated from homogeneous Wealden Shale samples 2-4 show bubble-point pressures of around 95 bar at $90 \%$ TR which corresponds to a theoretical (hydrostatic pressure) depth for phase separation of around $950 \mathrm{~m}$. On the other hand, petroleum fluids generated from the more heterogeneous sample 1 possess a bubble point of 135 bar at $90 \%$ TR which corresponds to a depth of around $1,350 \mathrm{~m}$. As can be revealed from well data and the $1 \mathrm{D}$ basin model, the Wealden Shale formation at the well location of Ex-B is buried to a present-day depth between 932 and $1,740 \mathrm{~m}$. Nevertheless, at the CretaceousTertiary border (67-63 Mya), the Wealden formation was further uplifted to a minimum depth of $717 \mathrm{~m}$ at its top and $1,525 \mathrm{~m}$ at its bottom. Thus and assuming zero secondary cracking (unlikely), retained fluids within the upper depth interval of well Ex-B, derived from both homogeneously and heterogeneously type I organic matter, would have reached their bubble-point pressure at hydrostatic pressures of approximately 70-90 bar and would have dissolved into a two-phase state of coexisting oil and gas. In contrast, petroleum fluids generated from homogeneous lacustrine organic matter and trapped within older Wealden horizons in times of maximum uplift were all positioned at depth levels below $\approx 950 \mathrm{~m}$ and therefore experienced hydrostatic pressures exceeding their bubble points at 95 bar. They could have only occurred as a single undersaturated oil phase. The latter is only true for the 4th depth interval of the here investigated sample set assuming composition of retained fluids derived from organic matter resembling that of the more heterogeneous sample 1 . In the 2nd and 3 rd depth interval, those fluids (bubble-point pressures of $\approx 135$ bar) would have undergone phase separation.

Secondary cracking processes affecting the petroleum composition of primarily generated fluids are completely neglected in this scenario. Nevertheless, it is very likely

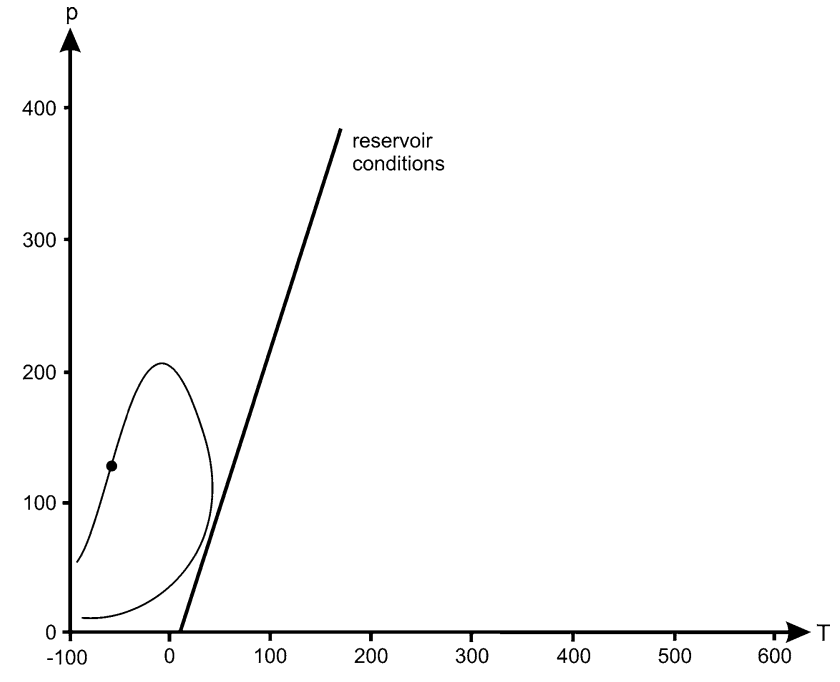

Fig. 8 Phase envelope of a dry gas (after di Primio et al. 1998). Note that no phase separation can occur under natural pressure-temperature conditions

that "near complete" secondary cracking of retained hydrocarbons took place by exposure to higher temperatures during times of maximum burial to maturity levels around 2.2-2.4\% VR $\mathrm{VR}_{\mathrm{r}}$ (Rippen et al. 2013). It should be noted here that for the two lacustrine Wealden Shale samples compositional secondary cracking kinetics were determined using MSSV pyrolysis at three different heating rates and the GOR $_{\text {FIT }}$ model (Mahlstedt et al. 2013). Presentation of those results is outside the scope of this paper, but it can be stated here that the end of the secondary conversion of primary petroleum to gas was calculated to occur at $\sim 2.2 \%$ easy $R_{0}$ for products of sample 1 and $\sim 2.3 \%$ easy $R_{0}$ for products of sample $4\left(3{ }^{\circ} \mathrm{C} / \mathrm{Ma}\right.$ heating rate). Furthermore, it is well known that in-source secondary cracking proceeds much faster than in-reservoir secondary cracking and can be generally assumed to be completed before $2.0 \%$ VR (Schenk et al. 1997a, b; Dieckmann et al. 1998; Hill et al. 2007; Horsfield et al. 1992). Generation of secondary gas from primary petroleum products within the Wealden sequence would therefore leave behind a pyrobitumen and, still assuming zero expulsion, fluids characterised by much higher GORs and therefore phase envelopes with much higher cricondenbars and lower cricondentherms (Fig. 8, compare to Fig. 17 in di Primio et al. (1998)). Consequently, retained fluids in all depth intervals of well Ex-B should occur at maximum burial depth as an undersaturated gas or condensate phase, which, depending on its GOR or gas dryness, might not be able to reach its dew point and consequently two-phase state even during uplift to surface pT-conditions. Looking into the profile of thermovaporisation gas chromatographic fingerprints of samples from well Ex-B (Fig. 10 in Rippen et al. 2013), it becomes clear 
that, in concordance with the above discussed, low overall amounts of free compounds within the lower three depth intervals can be described as gas condensates. Nevertheless, in the upper interval, at $2.2 \% \mathrm{VR}_{\mathrm{r}}$, paraffinic hydrocarbons dominated by intermediate chain length $\left(n-\mathrm{C}_{13-15}\right)$ and essentially no gas are encountered which are therefore unlikely to reflect originally retained petroleum compounds, at least when following the here presented thermal burial and uplift history. In this context, impregnation of rocks within this interval by migrated oil of for now unknown origin is more likely, whereas timing of migration and emplacement is as well unknown. Impregnating oils probably originate from another source rock horizon within the LSB (Wealden, Posidonia Shale or Carboniferous strata) that generated more recently.

An additional scenario for phase separation, that is, phase separation during migration of expelled hydrocarbons into lower pressurised depth regions, is thinkable and more realistic than the previously described scenario. Wealden Shales can be described as a type I source rock if not oil shale characterised by $\mathrm{HI}$ values exceeding $600 \mathrm{mg}$ HC/g TOC. According to Pepper and Corvi (1995), the major amount of the TOC of those kinds of rocks is reactive kerogen and can be converted into expellable petroleum because their sorptive capacity, defined by the amount of inert kerogen (which is low as the HI is high), is low. Usually up to $90 \%$ of the total organic matter of oil shales such as the Green River Shale is converted to oil and is expelled. Due to the very narrow maturity range over which petroleum formation is predicted to proceed for the investigated lacustrine samples, a rapid pressure built-up can be expected to occur in course of the quick volume expansion of the reaction kerogen to oil and gas. This might induce primary migration rather via natural fracturing of the rock than via the pore network (Düppenbecker et al. 1991) as pressure built-up within the pores quickly exceeds rock integrity. A micro-fracture system predominantly parallel to the bedding plane is often observed in high-quality oil-generating source rocks which allowed an outward flow of oil through the spontaneously generated fracture system leading to pressure release. Formation of such a fracture system in the case of the Wealden Shale is indicated by bitumen (pyrobitumen) accumulation within the matrix, pore spaces as well as natural fractures of samples from overmature well Ex-B (compare Rippen et al. 2013). One known conventional oil accumulation believed to have been sourced already during Lower Cretaceous times, prior to inversion, by the Wealden Shale is the Bramberge oil field in Northern Germany (Grassmann et al. 2006); hence, migration is documented as having taken place.

For phase separation to occur during upwards migration, large distances would have had to be overcome: for fluids derived from less homogeneous and less stable lacustrine type I organic matter (resembling sample 1) vertical distances of approximately $1 \mathrm{~km}$ (generation at 210-293 bar for $10-90 \%$ TR, bubble-point pressure $\approx 135$ bar) and for fluid derived from homogeneous, stable lacustrine type I organic matter (resembling samples 2-4) vertical distances of approximately $2 \mathrm{~km}$ (generation at 259-333 bar for $10-90 \%$ TR, bubble-point pressure $\approx 95$ bar). Phase separation during vertical migration is very hard to model and beyond the scope of the work described here. Nevertheless, there might be indication of phase separation during long distance, lateral migration upwards within the source bed or adjacent strata. This indication can be inferred from the discussed bitumen filled natural fractures observed in samples of well Ex-B in connection with the still very high TOC contents of those samples compared with equivalent immature samples from well Ex-A (compare Rippen et al. 2013). If high contents of the original TOC were indeed expelled, as it is usually the case for type I source rocks, TOC contents at higher maturities should be significantly lower. Thus, it could be argued that organic matter within high maturity samples is largely derived from upwards migrated petroleum which reached bubble-point pressures and experienced phase separation, with the exsolving gas phase being lost and the oil phase, enriched in high molecular weight paraffinic compounds, being left behind as immobile bitumen plugging the pore space. Evidence for such a process might be derived from methane fluid inclusions within calcite fracture fillings of horizontal veins found in close association with the here investigated organic matter-rich horizons in the four depth intervals of well Ex-B (Lüders and Plessen 2012; unpublished results). Those horizontal veins are usually the result of mineralisation of hydraulic expulsion fractures, which developed, in close relation to the previous discussed natural fracturing during petroleum generation, in the course of exsolution of gas from a saturated oil phase, a process causing volume expansion and overpressure.

Please keep in mind that the latter scenario is still speculative and complete fluid movement were not attempted to being modelled within the scope of this work. The discussion is rather motivated by showing possibilities of how PhaseKinetics data can be applied into geological systems.

\section{Conclusion}

Within the LSB, the Wealden Shale was deposited during the earliest Cretaceous (Berriasian) from 145 to 137 Mya and, according to the model of Bruns et al. (2013b) immediately underwent a rapid burial to $4,800 \mathrm{~m}$ within $56 \mathrm{Ma}$ in the area of a pseudo-well situated at the location of well Ex-B leading to maximum temperatures of $226{ }^{\circ} \mathrm{C}$. The subsequent basin history was strongly influenced by an 
inversion of the basin between 89 and 65 Mya removing nearly the entire Cretaceous sedimentary record at some locations. At present, the Wealden formation is covered by $932 \mathrm{~m}$ of Cretaceous and Cenozoic sediments at the well location Ex-B.

Bulk kinetic modelling revealed that the organic matter present in sample 1 is thermally more instable and shows a broader activation energy distribution resulting in a slower conversion to oil and gas at lower temperatures $\left(T_{\max }\right.$ of $148.4{ }^{\circ} \mathrm{C}$ ). The organic matter of the more homogeneous samples $2-4$ is thermally more stable $\left(T_{\max }\right.$ between 165.6 and $170.5^{\circ} \mathrm{C}$ ) and is converted faster. The fluids exhibit low GORs below $100 \mathrm{Sm}^{3} / \mathrm{Sm}^{3}$ that do not significantly change throughout kerogen conversion which is a typical feature for homogeneously structured type I kerogens. Consequently, $P_{\text {sat }}$ and $\mathrm{B}_{\mathrm{O}}$ do also range within a limited area. All of the samples possess high generation potentials for heavy components $\left(\mathrm{C}_{7+}\right)$, that is, paraffinic high-wax oils, whereas fluids from samples $2-4$ are more enriched in very heavy fractions $\left(\mathrm{C}_{14-45}\right)$ compared with those from sample 1. This is also reflected in the phase envelopes which are "flatter" for homogeneous kerogen containing samples 2-4. Phase separation would proceed at lower depths than for fluids derived from sample 1 .

This basin offers the benefit of having similar organofacies at different maturation stages, as well as having the overmature well Ex-B to act as reference to predict the possible pT-conditions of already generated oil and gas at the distinct present-day reservoir depths. Therefore, the bulk kinetic parameters of samples 1 and 4 were included in a 1D geologic basin model for the well Ex-B assuming that petroleum fluids generated from samples of this well contain the same compositions, and thus physical properties, as hydrocarbons from the samples of the immature well Ex-A. The onset of hydrocarbon generation using the bulk kinetics of the homogeneous organic matter-containing sample 4 was predicted to occur at a depth of $2,670 \mathrm{~m}$ (115 Mya) and the offset at 105 Mya at around 3,313 m depth. Applying the kinetic parameters of the more heterogeneous organic matter-containing sample 1 petroleum generation occurred within a quite broader depth as well as time interval ranging from $2,100 \mathrm{~m}$ (122 Mya) to 2,950 m (111 Mya). At these subsurface pT-conditions hydrocarbons are generated and expelled as a single liquid phase of oil undersaturated in dissolved gas. During geological uplift to a minimum depth of 717 (top) and 1,525 m (bottom) fluids derived from organic matter resembling that in sample 1 and trapped in the upper interval might have experienced a phase separation into a gas phase and a saturated fluid phase, whereas fluids in the lower intervals did at no time experience pT-conditions falling below their bubble-point pressures and therefore remain in an undersaturated single-phase state.
However, one can assume that severe secondary cracking of retained hydrocarbons took place leading to a strong increase in the GOR and a shift of phase envelopes to higher saturation pressures. Hence, phase separation could have occurred at much greater depths. Nevertheless and by comparison of free HC GC traces to the findings of bulk kinetics and phase behaviour, it becomes likely that migrated oil of unknown origin impregnated the upper horizon of well Ex-B. An alternative but speculative scenario is that severe natural fracturing due to pore pressure increase during rapid primary petroleum generation induces primary migration of products to lower situated Wealden horizons where phase separation can occur leaving behind waxy and immobile bitumen. Still very high TOC contents of the mature samples in comparison with immature samples as well as methane fluid inclusions within calcite fracture fillings could bear evidence for this process.

Acknowledgments As this study was carried out in course of the "GASH—Gas Shales in Europe" initiative, the authors wish to thank the sponsors of this project for providing sample material. Special thank goes to Ferdinand Perssen for technical guidance during the lab work.

Open Access This article is distributed under the terms of the Creative Commons Attribution License which permits any use, distribution, and reproduction in any medium, provided the original author(s) and the source are credited.

\section{References}

Behar F, Derenne S, Largeau C (1995) Closed pyrolyses of the isoprenoid algaenan of Botryococcus braunii, L. race: geochemical implications for derived kerogens. Geochim Cosmochim Acta 59(14):2983-2997. doi:10.1016/0016-7037(95)00189-1

Berner U (2011) The German Wealden, an unconventional hydrocarbon play? Erdöl Erdgas Kohle 127(7/8):303-307

Berner U, Kahl T, Scheeder G (2010) Hydrocarbon potential of sediments of the German Wealden Basin. Oil Gas Eur Mag 36(2):80-84

Betz D, Führer F, Greiner G, Plein E (1987) Evolution of the Lower Saxony Basin. Tectonophysics 137(1-4):127-170. doi:10.1016/0040-1951(87)90319-2

BGR (2012) Abschätzung des Erdgaspotenzials aus dichten Tongesteinen (Schiefergas) in Deutschland (trans: Fachbereich B1.3-Geologie der Energierohstoffe P). Bundesanstalt für Geowissenschaften und Rohstoffe (BGR), Hannover

Blumenstein IO, Krooss BM, di Primio R, Rottke W, Muller E, Westerlage C, Littke R (2008) Biodegradation in numerical basin modelling: a case study from the Gifhorn Trough, N-Germany. Int J Earth Sci 97(5):1115-1129. doi:10.1007/s00531-007-0272-1

Braun RL, Burnham AK, Reynolds JG, Clarkson JE (1991) Pyrolysis kinetics for lacustrine and marine source rocks by programmed micropyrolysis. Energy Fuels 5(1):192-204. doi:10.1021/ ef00025a033

Brink HJ, Dürschner H, Trappe H (1992) Some aspects of the late and post-Variscan development of the Northwestern German Basin. Tectonophysics 207(1-2):65-95. doi:10.1016/0040-1951(92)90472-i 
Bruns B, di Primio R, Berner U, Littke R (2013a) New insights on the maturity distribution and shale gas potential of the Lower Saxony Basin, NW-Germany. Paper presented at the DGMK-ÖGEWFrühjahrstagung 2013, Fachbereich Aufsuchung und Gewinnung, Celle, 18-19 April 2013

Bruns B, di Primio R, Berner U, Littke R (2013b) Petroleum system evolution in the inverted Lower Saxony Basin, northwest Germany: a 3D basin modeling study. Geofluids 13(2):246-271. doi:10.1111/gfl.12016

Burnham AK, Braun RL, Gregg HR, Samoun AM (1987) Comparison of methods for measuring kerogen pyrolysis rates and fitting kinetic parameters. Energy Fuels 1(6):452-458. doi:10.1021/ ef00006a001

de Jager J (2003) Inverted basins in the Netherlands, similarities and differences. Neth J Geosci 82(4):355-366

de Leeuw JW, Largeau C (1993) A review of macromolecular organic compounds that comprise living organisms and their role in kerogen, coal, and petroleum formation. In: Engel MH, Macko SA (eds) Organic geochemistry: principles and applications. Topics in geobiology, vol 11. Plenum Press, New York, pp 23-72

di Primio R, Horsfield B (2006) From petroleum-type organofacies to hydrocarbon phase prediction. AAPG Bull 90(7):1031-1058. doi:10.1306/02140605129

di Primio R, Skeie JE (2004) Development of a compositional kinetic model for hydrocarbon generation and phase equilibria modelling: a case study from Snorre Field, Norwegian North Sea. Geological Soc, London, Special Publications vol 237, no 1, pp 157-174. doi:10.1144/gsl.sp.2004.237.01.10

di Primio R, Dieckmann V, Mills N (1998) PVT and phase behaviour analysis in petroleum exploration. Org Geochem 29(1-3):207222. doi:10.1016/s0146-6380(98)00102-8

Dieckmann V, Schenk HJ, Horsfield B, Welte DH (1998) Kinetics of petroleum generation and cracking by programmed-temperature closed-system pyrolysis of Toarcian Shales. Fuel 77(1-2):23-31

Düppenbecker SJ, Dohmen L, Welte DH (1991) Numerical modelling of petroleum expulsion in two areas of the Lower Saxony Basin, Northern Germany. In: England WA, Fleet AJ (eds) Petroleum migration, vol 59. Geological Society Special Publications, London, pp 47-64. doi:10.1144/gsl.sp.1991.059.01.04

Elstner F, Mutterlose J (1996) The Lower Cretaceous (Berriasian and Valanginian) in NW Germany. Cretac Res 17(1):119-133. doi:10.1006/cres.1996.0010

England WA, Mackenzie AS (1989) Some aspects of the organic geochemistry of petroleum fluids. Geol Rundsch 78(1):291-303

England WA, Mackenzie AS, Mann DM, Quigley TM (1987) The movement and entrapment of petroleum fluids in the subsurface. J Geol Soc 144(2):327-347. doi:10.1144/gsjgs.144.2.0327

Fabian HJ (1963) Das Erdölfeld Meckelfeld-Süd. Erdöl-Z 79 Jg 1-9

Fuhrmann A, Horsfield B, Lòpez JF, Hu L, Zhang Z (2004) Organic facies, depositional environment and petroleum generating characteristics of the lacustrine Shahejie Formation, ES4 member, Western Depression, Liaohe Basin (NE China). J Pet Geol 27(1):27-46. doi:10.1111/j.1747-5457.2004.tb00043.x

Gelpi E, Schneider H, Mann J, Oró J (1970) Hydrocarbons of geochemical significance in microscopic algae. Phytochemistry 9(3):603-612. doi:10.1016/S0031-9422(00)85700-3

Grassmann S, Cramer B, Winsemann J (2006) Influence of inversion tectonics on the formation of the Bramberge oil field, Northern Germany. Zeitschrift der Deutschen Gesellschaft für Geowissenschaften 157(2):263-277. doi:10.1127/1860-1804/2006/0157-0263

Hill RJ, Jarvie DM, Zumberge J, Henry M, Pollastro RM (2007) Oil and gas geochemistry and petroleum systems of the Fort Worth Basin. AAPG Bull 91(4):445-473. doi:10.1306/11030606014

Horsfield B (1989) Practical criteria for classifying kerogens: some observations from pyrolysis-gas chromatography. Geochim Cosmochim Acta 53(4):891-901
Horsfield B, Dueppenbecker SJ (1991) The decomposition of Posidonia Shale and Green River Shale kerogens using microscale sealed vessel (MSSV) pyrolysis. J Anal Appl Pyrolysis 20:107123. doi:10.1016/0165-2370(91)80066-H

Horsfield B, Disko U, Leistner F (1989) The micro-scale simulation of maturation: outline of a new technique and its potential applications. Geol Rundsch 78(1):361-373. doi:10.1007/bf01988370

Horsfield B, Heckers J, Leythaeuser D, Littke R, Mann U (1991) A study of the Holzener Asphaltkalk, northern Germany; observations regarding the distribution, composition and origin of organic matter in an exhumed petroleum reservoir. Mar Pet Geol 8(2):198-211

Horsfield B, Schenk HJ, Mills N, Welte DH (1992) An investigation of the in-reservoir conversion of oil to gas: compositional and kinetic findings from closed-system programmed-temperature pyrolysis. Org Geochem 19(1-3):191-204

Horsfield B, Curry DJ, Bohacs K, Littke R, Rullkötter J, Schenk HJ, Radke M, Schaefer RG, Carroll AR, Isaksen G, Witte EG (1994) Organic geochemistry of freshwater and alkaline lacustrine sediments in the Green River Formation of the Washakie Basin, Wyoming, USA. Org Geochem 22(3-5):415-440

Kenig F, Huc AY, Purser BH, Oudin JL (1990) Sedimentation, distribution and diagenesis of organic matter in a recent carbonate environment, Abu Dhabi, UAE. Org Geochem 16(4-6):735-747. doi:10.1016/0146-6380(90)90113-E

Kockel F, Wehner H, Gerling P (1994) Petroleum systems of the Lower Saxony Basin, Germany. In: Magoon LB, Dow WG (eds) The petroleum system: from source to trap vol 60. AAPG Memoirs, Tulsa, pp 573-586

Kuhn P, di Primio R, Horsfield B (2010) Bulk composition and phase behaviour of petroleum sourced by the Bakken Formation of the Williston Basin, vol 7. Geological Society, London. doi: $10.1144 / 0071065$

Largeau C, Casadevall E, Kadouri A, Metzger P (1984) Formation of Botryococcus-derived kerogens-comparative study of immature torbanites and of the extent alga Botryococcus braunii. Org Geochem 6:327-332. doi:10.1016/0146-6380(84)90054-8

LBEG (2014) Erdöl-und Erdgasreserven in der Bundesrepublik Deutschland am 1. Januar 2014. LBEG Niedersachsen (Landesamt für Bergbau, Energie und Geologie). http://www.lbeg.niedersachsen.de/download/85821/Erdoel__und_Erdgasreserven_in_ der_Bundesrepublik_Deutschland_am_01.01.2014.pdf

Lübben H (1969) Grundgegebenheiten für Planung und Ablauf der Förderung aus den Emsländischen Valendis-Lagerstätten. Erdöl und Kohle 22 Jd. 373-377 u. 449-455

Lüders V, Plessen B (2012) Carbon isotopic compositions of gasbearing fluid inclusions in calcite fracture fillings hosted by Wealden shale, Lower Saxony Basin (Germany) (trans: Geochemistry $\mathrm{SO})$. GASH-Gas Shales in Europe, 3rd year report. GFZ German Research Centre for Geosciences, Potsdam

Lüders V, Plessen B, di Primio R (2012) Stable carbon isotopic ratios of $\mathrm{CH}_{4}-\mathrm{CO}_{2}$-bearing fluid inclusions in fracture-fill mineralization from the Lower Saxony Basin (Germany) - a tool for tracing gas sources and maturity. Mar Pet Geol 30(1):174-183. doi:10.1016/j.marpetgeo.2011.10.006

Mahlstedt N, Di Primio R, Horsfield B (2013) GOR-fit - From liquids to late gas: Deconvoluting primary from secondary gas generation kinetics. Book of Abstracts of the Communications, 26th International Meeting on Organic Geochemistry - IMOG (Costa Adeje, Tenerife Spain 2013), Costa Adeje, Tenerife, Spain 15-20 September 2013, pp 193-194

Mann U, Hantschel T, Schaefer RG, Krooss B, Leythaeuser D, Littke R, Sachsenhofer RF (1997) Petroleum migration: mechanisms, pathways, efficiencies and numerical simulations. In: Welte D, Horsfield B, Baker D (eds) Petroleum and basin evolution. Springer, Berlin, pp 403-520. doi:10.1007/978-3-642-60423-2_8 
McCain WD (1990) The properties of petroleum fluids, 1st edn. PennWell, Tulsa

Metzger P, Largeau C (2005) Botryococcus braunii: a rich source for hydrocarbons and related ether lipids. Appl Microbiol Biotechnol 66(5):486-496

Muscio G, Horsfield B, Welte D (1991) Compositional changes in the macromolecular organic matter (kerogens, asphaltenes and resins) of a naturally matured source rock sequence from Northern Germany as revealed by pyrolysis methods. In: Manning D (ed) Organic geochemistry: advances and applications in the natural environment, vol 15. Manchester University Press, Manchester and New York, pp 447-449

Mutterlose J, Bornemann A (2000) Distribution and facies patterns of Lower Cretaceous sediments in northern Germany: a review. Cretac Res 21(6):733-759. doi:10.1006/cres.2000.0232

Nebe DW (1999) Zyklenuntersuchungen an unterkretazischen Sedimenten in NW-Deutschland: Nachweisbarkeit von MilankovitchZyklen. Dissertation, RU Bochum, Bochum

Pelzer G, Riegel W, Wilde V (1992) Depositional controls on the Lower Cretaceous Wealden coals of northwest Germany. In: McCabe P, Parrish J (eds) Controls on the distribution and quality of Cretaceous coals, vol 267. Geological Society of America Special Paper, Boulder, pp 227-244

Pepper AS, Corvi PJ (1995) Simple kinetic models of petroleum formation. Part III: modelling an open system. Mar Pet Geol 12(4):417-452. doi:10.1016/0264-8172(95)96904-5

Pepper AS, Dodd TA (1995) Simple kinetic models of petroleum formation. Part II: oil-gas cracking. Mar Pet Geol 12(3):321-340. doi:10.1016/0264-8172(95)98382-f

Petmecky S, Meier L, Reiser H, Littke R (1999) High thermal maturity in the Lower Saxony Basin: intrusion or deep burial? Tectonophysics 304(4):317-344. doi:10.1016/s0040-1951(99)00030-x

Rippen D, Littke R, Bruns B, Mahlstedt N (2013) Organic geochemistry and petrography of Lower Cretaceous Wealden black shales of the Lower Saxony Basin: the transition from lacustrine oil shales to gas shales. Org Geochem 63:18-36. doi:10.1016/j. orggeochem.2013.07.013

Rullkötter J (1993) The thermal alteration of kerogen and the formation of oil. In: Engel MH, Macko SA (eds) Organic geochemistry: principles and applications, vol 11. Topics in geobiology. Plenum Press, New York and London, pp 377-396

Rullkötter J, Leythaeuser D, Horsfield B, Littke R, Mann U, Müller PJ, Radke M, Schaefer RG, Schenk HJ, Schwochau K, Witte EG, Welte DH (1988) Organic matter maturation under the influence of a deep intrusive heat source: a natural experiment for quantitation of hydrocarbon generation and expulsion from a petroleum source rock (Toarcian shale, northern Germany). Org Geochem 13(4-6):847-856
Sachsenhofer RF, Curry DJ, Horsfield B, Rantitsch G, Wilkes H (1995) Characterization of organic matter in late Cretaceous black shales of the Eastern Alps (Kainach Gosau Group, Austria). Org Geochem 23(10):915-929. doi:10.1016/0146-6380(95)00072-0

Schaefer RG, Schenk HJ, Hardelauf H, Harms R (1990) Determination of gross kinetic parameters for petroleum formation from Jurassic source rocks of different maturity levels by means of laboratory experiments. Org Geochem 16(1-3):115-120. doi:10.1016/0146-6380(90)90031-t

Schenk HJ, Horsfield B (1993) Kinetics of petroleum generation by programmed-temperature closed-versus open-system pyrolysis. Geochim Cosmochim Acta 57(3):623-630. doi:10.1016/0016-7037(93)90373-5

Schenk HJ, Di Primio R, Horsfield B (1997a) The conversion of oil into gas in petroleum reservoirs. Part 1: comparative kinetic investigation of gas generation from crude oils of lacustrine, marine and fluviodeltaic origin by programmed-temperature closed-system pyrolysis. Org Geochem 26(7-8):467-481

Schenk HJ, Horsfield B, Krooss BM, Schaefer RG, Schwochau K (1997b) Kinetics of petroleum formation and cracking. In: Welte DH, Horsfield B, Baker DR (eds) Petroleum and basin evolution: insights from petroleum geochemistry, geology and basin modeling. Springer, Berlin

Schwarzkopf T, Leythaeuser D (1988) Oil generation and migration in the Gifhorn Trough, NW-Germany. Org Geochem 13(1-3):245-253

Tegelaar EW, Noble RA (1994) Kinetics of hydrocarbon generation as a function of the molecular structure of kerogen as revealed by pyrolysis-gas chromatography. Org Geochem 22(3-5):543-574

Tegelaar EW, de Leeuw JW, Derenne S, Largeau C (1989) A reappraisal of kerogen formation. Geochim Cosmochim Acta 53(11):3103-3106. doi:10.1016/0016-7037(89)90191-9

Tissot BP, Pelet R, Ungerer P (1987) Thermal history of sedimentary basins, maturation indices, and kinetics of oil and gas generation. AAPG Bull 71(12):1445-1466

van Heek KH, Jüntgen H (1968) Bestimmung der reaktionskinetischen Parameter aus nichtisothermen Messungen. Ber Bunsenges Phys Chem 72(9-10):1223-1231. doi:10.1002/ bbpc. 19680720927

WEG (2013) Statistischer Bericht. http://www.erdoel-erdgas.de/ content/download/4850/51668/file/Statistischer\%20Bericht $\% 20$ 2013\%20.pdf

Welte DH, Horsfield B, Baker DRE (1997) Petroleum and basin evolution: insights from petroleum geochemistry, geology and basin modeling. Springer, Berlin 